\title{
The combined effect of essential oils and emerging technologies on food safety and quality
}

\author{
Geany Targino de Souza Pedrosa ${ }^{\mathrm{a}}$, Tatiana Colombo Pimentel ${ }^{\mathrm{b}}$, Mohsen Gavahian ${ }^{\mathrm{c}}$, \\ Lorena Lucena de Medeiros $^{\mathrm{d}}$, Rafael Pagán ${ }^{\mathrm{e}}$, Marciane Magnani ${ }^{\mathrm{a},}$ \\ ${ }^{a}$ Laboratory of Microbial Processes in Foods, Department of Food Engineering, Technology Center, Federal University of Paraíba, João Pessoa, Paraíba, Brazil \\ ${ }^{\mathrm{b}}$ Federal Institute of Paraná, Paranavaí, Paraná, Brazil \\ ${ }^{\mathrm{c}}$ Department of Food Science, National Pingtung University of Science and Technology, Neipu, 91201, Taiwan, ROC \\ ${ }^{\mathrm{d}}$ Department of Food Engineering, Technology Center, Federal University of Paraíba, João Pessoa, Paraíba, Brazil \\ ${ }^{\mathrm{e}}$ Departamento de Producción Animal y Ciencia de Los Alimentos, Facultad de Veterinaria, Instituto Agroalimentario de Aragón-IA2 (Universidad de Zaragoza-CITA), \\ Zaragoza, Spain
}

\section{A R T I C L E I N F O}

\section{Keywords:}

Microbial inactivation

Non-thermal technologies

Synergism

Ohmic heating

Sustainable food consumption

\begin{abstract}
A B S T R A C T
Essential oils (EOs) are natural food preservatives, but they may impair the sensory characteristics of foods. Emerging technologies (ETs) can inactivate microorganisms, but high intensities of the process may compromise quality parameters. This manuscript discusses the use of EOs and ETs and presents the mechanisms of microbial inactivation in combined processes. Also, the advantages, disadvantages, and limitations of EO and ETs were explained. It was found that lemongrass, lavender, thyme, sweet basil, lime, oregano, mentha, cinnamon, citral, carvacrol, carvone, geraniol, eugenol, citrus extract, mandarin, rosemary, and clove EOs have been combined with cold plasma, ultrasound, irradiation, ultraviolet light, high hydrostatic processing, pulsed light, pulsed electric fields, ohmic heating, and ozone to inactivate pathogens, spoilage bacteria, and molds. The food matrices explored for EO and ET include meat, fish, eggs, milk, plant-based products, as well as food-container surfaces. Synergistic effects between EOs and ETs have been reported in many cases. Microbial inactivation is influenced by the type of microorganism, the intensity of ET processing parameters, type and concentration of EOs, and the composition of foods. The combined use of EOs and ETs is a strategy capable of reducing the EO doses and the ET intensity while improving food safety and quality.
\end{abstract}

\section{Introduction}

Concerns regarding the damaging consequences of chemical preservatives and the negative effects of heat treatments on food commodities' sensory and nutritional characteristics have given rise to studies using natural antimicrobials and emerging technologies (ETs) (Mortazavi \& Aliakbarlu, 2019). Essential oils (EOs) have often been proposed as food preservatives due to their strong, wide-spectrum activity against microorganisms (Espina, García-Gonzalo, \& Pagán, 2014; Souza Pedrosa et al., 2019). However, the concentrations of EOs required to achieve a significant antimicrobial activity frequently exceed consumer rejection thresholds (Souza Pedrosa et al., 2019). For example, thyme EO at $0.9 \%$ was effective in reducing Salmonella sp. in minced pork meat, but the product acceptability lay below the acceptable limit (scores lower than 5) (Boskovic et al., 2017). EOs (lemongrass, garlic, oregano, rosemary, lemon, lime, onion, and thyme) were efficient as antimicrobial agents (Listeria spp.) in fresh fish. However, the products had low sensory acceptance associated with the EOs' strong flavors and odors, decreasing freshness perception (Pedrós-Garrido et al., 2020).

The application of ETs can inactivate microorganisms without perceptibly changing the sensory and nutritional characteristics of products if suitable processing parameters are used (Berdejo, Pagán, Gárcia-Gonzalo, \& Pagán, 2019). They can be categorized into thermal

Abbreviations: Essential oils, (EOs); Emerging technologies, (ETs); Ohmic heating, (OH); Cold plasma, (CP); Ultrasound, (US); Irradiation, (IR); Ultraviolet light, (UV-C); High hydrostatic processing, (HHP); Pulsed light, (PL); Pulsed electric fields, (PEF); Individual constituents, (ICs).

* Corresponding author. Laboratory of Microbial Processes in Foods, Department of Food Engineering, Technology Center, Federal University of Paraíba, Campus I, 58051-900, João Pessoa, Brazil.

E-mail addresses: magnani2@gmail.com,magnani2@pq.cnpq.br (M. Magnani). 
technologies, such as ohmic heating $(\mathrm{OH})$, and non-thermal technologies including cold plasma (CP), ultrasound (US), irradiation (IR), ultraviolet light (UV-C), high hydrostatic processing (HHP), pulsed light (PL), pulsed electric fields (PEF), and ozone technologies (Misra et al., 2017). In OH, an alternating current is passed through the food sample, resulting in uniform and rapid heating. Thermal effects promote microbial inactivation, although non-thermal effects (electroporation) may also be observed (Cappato et al., 2017). Non-thermal technologies may be applied at ambient temperature, and lead to microbial inactivation due to cell injuries and ruptures promoted by electric fields, cavitation, high pressure, radiation, among others (Misra et al., 2017). However, their efficacy against certain microorganisms is limited and dependent on processing parameters (Carvalho, Medeiros, Chaves, de Souza, \& Magnani, 2018). In some cases, a satisfying degree of decontamination cannot be achieved by ETs without compromising product quality (Gavahian, Peng, \& Chu, 2019).

The combined use of EOs with ETs could represent a possible alternative capable of decreasing the effective doses of EOs and the intensity of ETs, thereby resulting in greater rates of inactivation of microorganisms while ensuring a low impact of the process on food quality. Therefore, the utilization of EOs in combination with ETs may help increase the shelf-life of foods (Berdejo, García-Gonzalo, \& Pagán, 2019). Also, enhancing the safety and quality of food products through such combinations can help with sustainable food consumption which is among the sustainable development goals (SDGs). This manuscript provides an overview of the combined use of EOs with ETs in recently published studies, based on potential mechanisms and reported findings; moreover, it offers a critical discussion of the advantages, disadvantages, and limitations of this alternative processing approach.

\section{Methods}

In the present study, a narrative bibliographical review was carried out using Web of Science, Science Direct, PubMed, Scopus, and Lilacs platforms as scientific databases. The keywords used as descriptors were: "essential oils", "natural antimicrobial", "emerging technologies", "combined processes", "combined technologies", "essential oil constituents", "food preservation", "food safety", "food quality", "cold plasma”, "ultrasound", "irradiation", "ultraviolet light", "high hydrostatic processing", "pulsed light", "pulsed electric fields", "ozone", and "ohmic heating" as a search strategy. We selected articles published during the period from 2016 to 2020, written exclusively in English. Papers from previous years were maintained in the article base if the reported findings were deemed to be of considerable importance for overall discussion or if they had not been cited in reviews already published. Papers that did not coincide with our subject, including classical technologies, case series, case-control, and repeated papers available on different platforms, were excluded. Two authors independently performed the screening and selection to form the article base for this overview.

A total of 36 studies are evaluated in this review, categorically subdivided according to the type of ET applied, and their results are discussed. Because the review focuses on combined technologies, including EOs, published data using EOs or ETs as single food preservation agents are not included. Several researchers refer to individual constituents (ICs) as EOs; thus, the original designation used in the studies was maintained.

\section{EOs: physical and chemical characteristics}

EOs are aromatic, volatile oily liquids produced in several parts of plants. They are mixtures of various chemical compounds, mainly terpenes. The antimicrobial activity of EOs is dependent on their characteristics (hydrophobic or hydrophilic), chemical compounds, and microorganism type (Reyes-Jurado et al., 2020). The nature of their ICs defines their bioactivity, and the antimicrobial effect follows an order of phenols $>$ aldehydes $>$ ketones $>$ alcohols $>$ ethers $>$ hydrocarbons
(Barbosa et al., 2016). Nevertheless, one or two ICs account for the largest portion of EOs composition (Begun et al., 2020).

EOs exert a multi-target action on microbial cells both in pathogenic and spoilage microorganisms, mainly due to the hydrophobic nature of their ICs, which leads to the partition of lipids in the cell membrane, thereby increasing its permeability (Souza Pedrosa et al., 2019; Berdejo et al., 2019).

Regarding antifungal activity, the effects of EOs are mainly related to the effectiveness of their components in terms of depolarization induction and physical or chemical modifications of fungal cell membranes, compromising metabolic activity and synthesis in fungal cells. Such phenomena may affect morphogenesis and hyphae/mycelial growth, resulting in antifungal effects (Braga et al., 2019). In addition, EOs trigger the apoptotic-induced death of fungi by raising the amount of intracellular reactive oxygen species (ROS) and increasing the peroxidation of lipids (Hossain et al., 2019a). Regarding bacteria, loss of ions and decrease in the membrane potential are responsible for membrane permeabilization, resulting in the collapse of the proton pump and depletion of the ATP pool (Reyes-Jurado et al., 2020). Gram-negative bacteria have less susceptibility to EOs than Gram-positive bacteria, mainly because the lipophilic compounds of EOs can enter through the thick layer of peptidoglycan of Gram-positive bacteria, altering the integrity of the cell membrane (phospholipid bilayer) and interfering with the protein transport. However, the EOs compounds may not enter through the Gram-negative bacteria's lipopolysaccharide membrane (Prakash, Baskaran, Paramasivam, \& Vadivel, 2018).

EOs are categorized as "generally recognized as safe" (GRAS) by the US Food and Drug Administration in its Code of Federal Regulation (CFR) (FDA, 2016). For the amounts used in food preservation systems, an absence of toxic effects has been reported (Deng et al., 2020). The advantages of EOs are their association with wholesome foods, the fact that they are natural or non-chemically synthesized, antibacterial, and are considered environment-friendly preservation processes.

The main drawback of using EOs in foods is their strong flavor and odor. The amounts required for microbial inactivation in foods commonly exceed the sensory rejection threshold (Souza Pedrosa et al., 2019). Besides, these substances are volatile, heat-labile, and have extremely low solubility in water due to their lipophilic character: therefore, they are generally used in emulsions with stabilizers. Strategies such as micro-and nanoencapsulation of EOs using appropriate vehicles may enhance the stability of active compounds, help avoid their oxidation and degradation, improve their water solubility, and mask the undesirable flavoring properties (Carvalho et al., 2018; Donsì et al., 2015).

The EOs constituents can interact with food components and intrinsic factors of foods, thereby affecting the EOs' antimicrobial effectiveness. It has been reported that at more acidic $\mathrm{pH}$ values, EO components bind better to the cell membrane, and the lipid membrane thus dissolves more easily (Millan-Sango, Garroni, Farrugia, Van Impe, \& Valdramidis, 2016). In addition, the inhibitory effects of EOs against pathogens in food matrices can be enhanced by the interaction between lipids and acids (Carvalho et al., 2018).

The combined use of EOs with ETs has attracted attention in recent years. Such approaches were proposed to ensure microbial inactivation. EOs combined with other ETs can decrease treatment intensity, reduce processing duration, and/or reduce the required concentration of EOs (Cui, Wu, Li, \& Lin, 2016). Some of the most widely studied EOs and ICs combined with ETs for use in food preservation systems are summarized in Figs. 1 and 2, respectively. Fig. 3 presents the main mechanisms of action of EOs in combination with ETs.

\section{Essential oils and emerging technologies}

\subsection{Essential oils and cold plasma}

$\mathrm{CP}$ (cold plasma) is an ionized gas containing a series of substances 


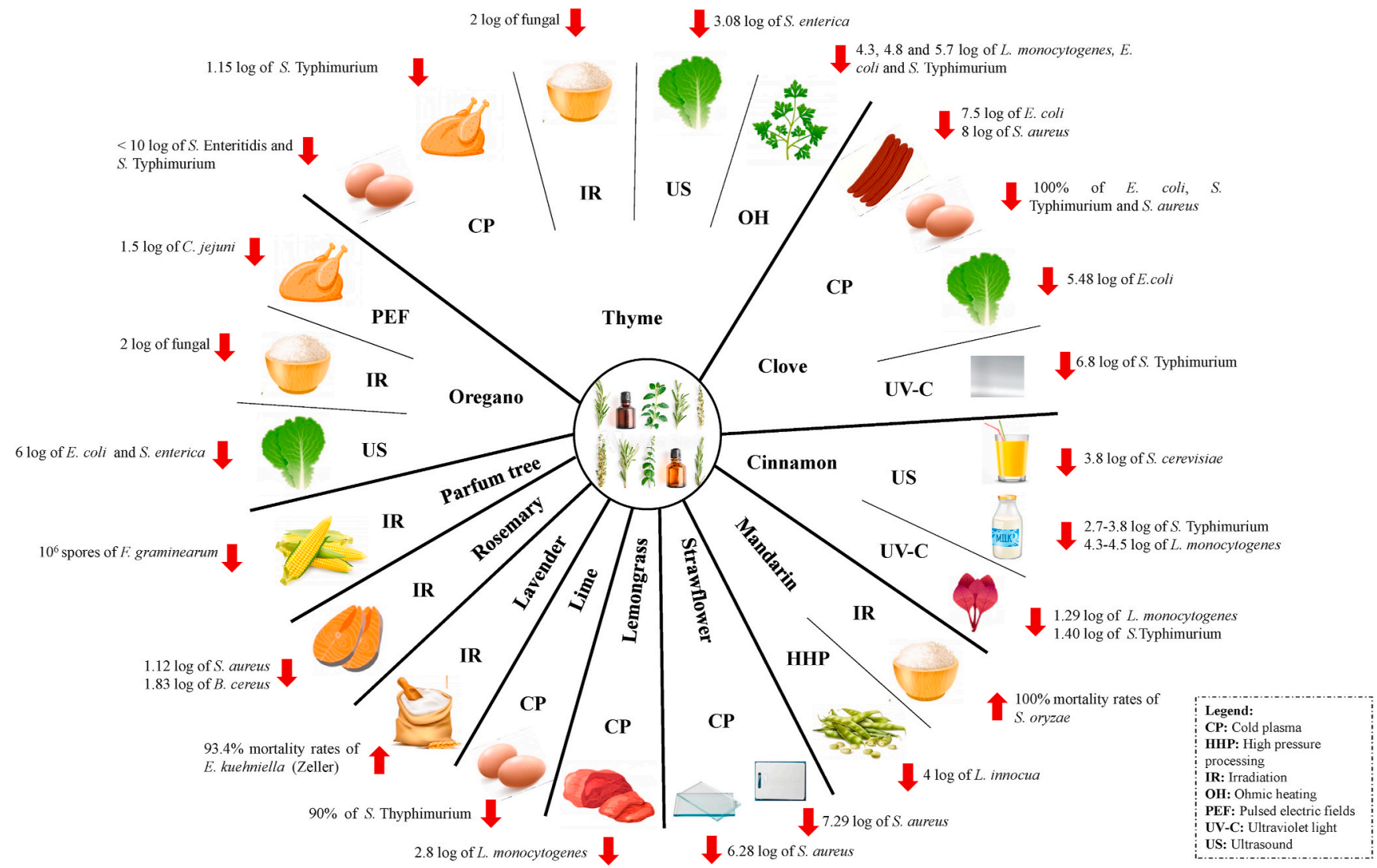

Fig. 1. Effects of essential oils combined with emerging technologies as applied in food matrix.

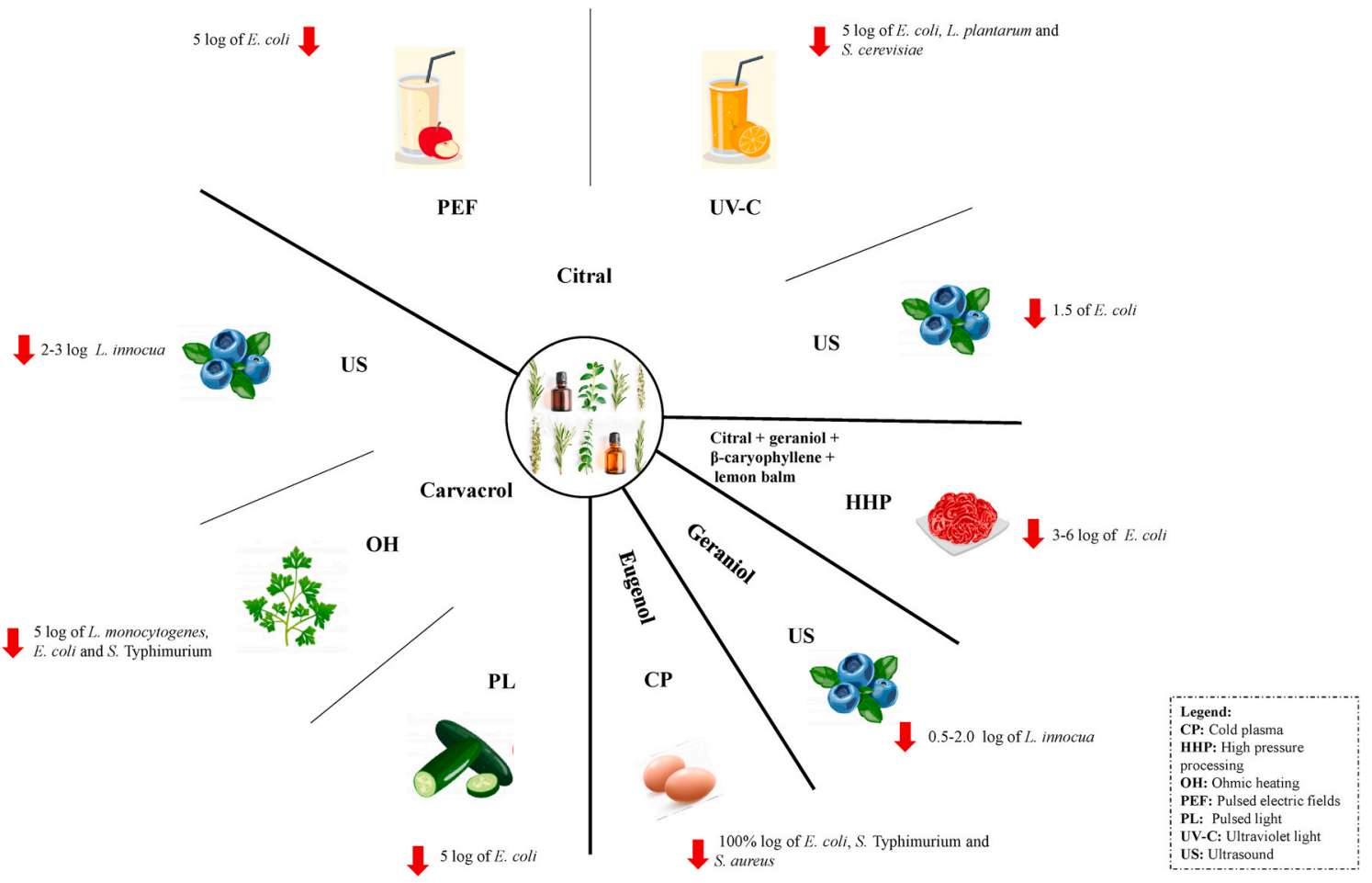

Fig. 2. Effects of individual components of essential oils in combination with emerging processing technologies applied in food matrix.

with antimicrobial properties, such as charged particles, electromagnetic fields, ROS, reactive nitrogen substances (RNS), and UV-C photons (Gavahian \& Cullen, 2020). CP is used at low temperatures $\left(30-60{ }^{\circ} \mathrm{C}\right.$ ) under reduced or atmospheric pressure. Furthermore, frequencies of $0.05-500 \mathrm{kHz}$, power of $20-500 \mathrm{~W}$, and gas pressures of $10^{4}-10^{6} \mathrm{~Pa}$ are commonly applied. The antimicrobial effect of $\mathrm{CP}$ is associated with its 


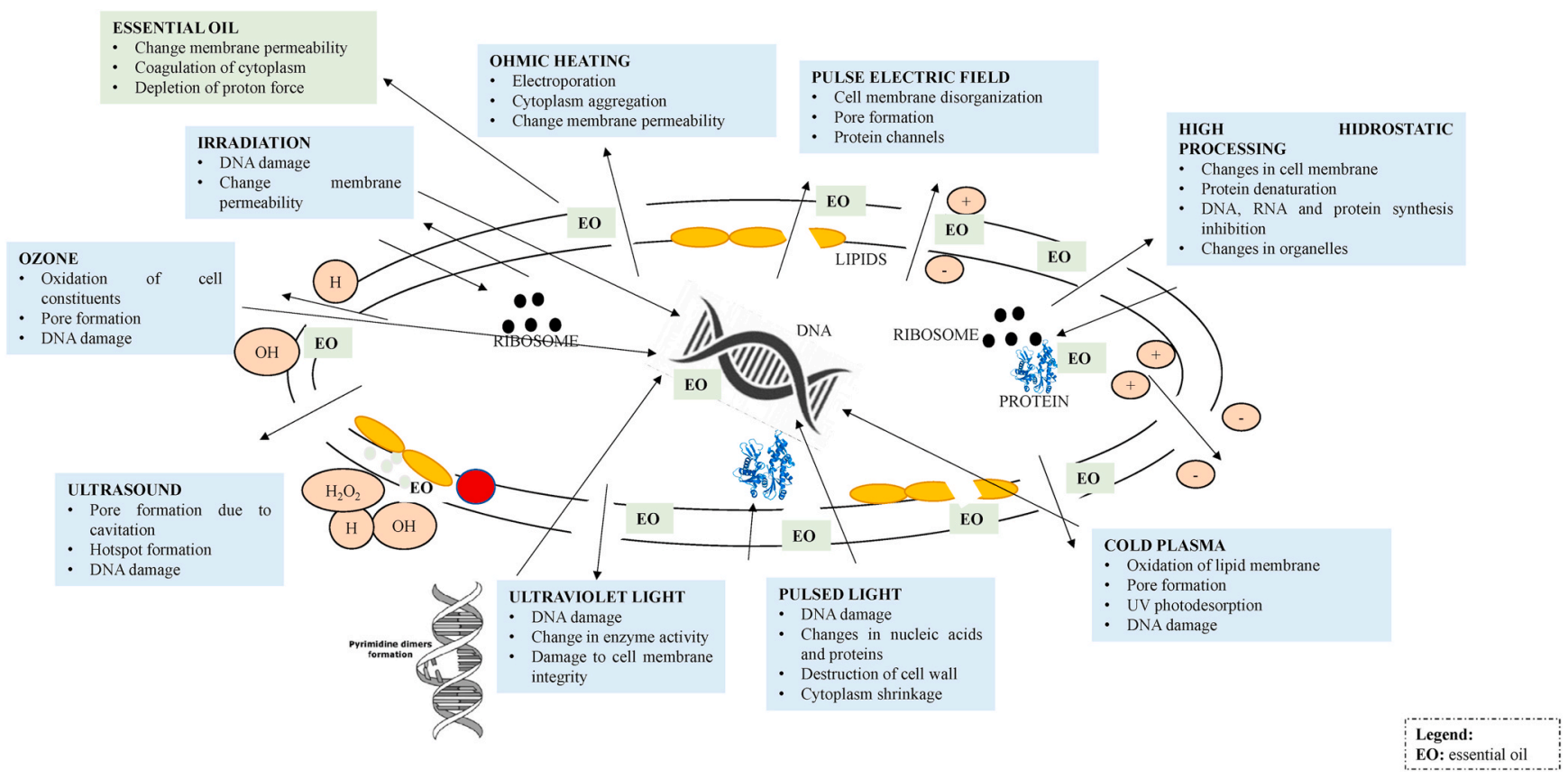

Fig. 3. Mechanisms of action of emerging technologies associated with essential oils. Adapted from Schlüter and Fröhling (2014).

components, which can have a considerable oxidative effect on the double bonds of the microbial cell's lipid bilayer and can be absorbed onto the microorganism's surface resulting in the formation of volatile compounds $\left(\mathrm{H}_{2} \mathrm{O}\right.$ and $\left.\mathrm{CO}_{2}\right)$. These compounds can form lesions on the microbial cell surface and impair macromolecules' transport outside and inside the cell, causing cell death. The cell rupture may also be provoked by the intense electric fields, mainly because of electrostatic tension. Furthermore, a photodesorption of UV-C photons and damage to the cell's genetic material may occur. The treatment's antimicrobial capacity is dependent on the $\mathrm{CP}$ processing parameters, such as gas composition, gas flow, electrical input (frequency, power, voltage), and treatment time (Coutinho et al., 2018).

CP offers many advantages as an antimicrobial technology (Table 2), such as high microbial inactivation rates at low temperatures. It is considered environmentally friendly, without residues, and energyefficient (the energy input needed is low), and it can be applied to both liquid and solid foods (Coutinho et al., 2018). Moreover, CP has a minimal impact on the nutritional value and sensory quality of foods. However, CP can lead to oxidation in products with a high-fat content (Gavahian, Chu, Khaneghah, Barba, \& Misra, 2018). Furthermore, the use of $\mathrm{CP}$ for the control of foodborne pathogens in foods may result in low levels of inactivation when this ET is used as a single treatment (Yoo, Baek, Heo, Yong, \& Jo, 2021), mainly in food products or containers with an irregular or bulky surface, because the ROS of CP has low penetration capacity. Furthermore, $\mathrm{CP}$ has a lower inactivation capacity for Gram-positive bacteria due to their denser membrane, resulting in a higher resistance than Gram-negative bacteria (Coutinho et al., 2018). Therefore, to achieve effective microbial decontamination, efforts have been made to combine $\mathrm{CP}$ with other antimicrobials, including EOs.

The combination of EOs and CP has been applied to increase meat products' quality and safety (Table 1). In a study with pork loin, it was observed that higher inactivation rates of $L$. monocytogenes could be observed with higher concentrations of lemongrass EO $(10 \mathrm{mg} / \mathrm{mL})$ for a longer treatment time (40 min) or increased CP power $(600 \mathrm{~W}$, cold nitrogen plasma device) for longer treatment times (180 s) when the technologies were used individually. However, the combined utilization of CP $(120 \mathrm{~s}, 500 \mathrm{~W})$ together with lemongrass EO (30 min, $5 \mathrm{mg} / \mathrm{mL})$ resulted in a synergistic antimicrobial effect against $L$. monocytogenes (4 $\log \mathrm{CFU} / \mathrm{g}$ ), with decreases of $2.80 \mathrm{log} \mathrm{CFU} / \mathrm{g}$ at lower concentrations of
EO, with lower $\mathrm{CP}$ power, and reduced treatment times. Furthermore, physicochemical properties such as texture, surface color, thiobarbituric acid reactive substances value (TBARS), and sensory attributes (e.g. color, appearance, off-flavor, taste, and overall acceptability) were not affected. In another study, a combination of thyme EO $(0.25 \mathrm{mg} / \mathrm{mL})$ and silk fibroin nanofiber (TO/SF) membrane treated with CP (400 W, 4 min, cold nitrogen plasma) was used to preserve samples of duck and chicken meat. Flavor and overall acceptability were improved when the combined treatment was used, and a reduction of Salmonella Typhimurium ( $1.5 \log \mathrm{CFU} / \mathrm{g}$ ) was observed after 7 days of storage. The authors concluded that plasma-TO/SF nanofibers can be used as effective antimicrobial packaging to enhance the shelf-life and quality of meat products; CP's utilization can improve the nanofiber microbial properties (Lin, Liao, \& Cui, 2019). In beef jerky, the combined treatment of CP (15 min, encapsulated atmospheric pressure plasma) and clove EO (1\%) decreased greater than $7.5 \log \mathrm{CFU} / \mathrm{g}$ for Escherichia coli O157:H7 and 8 $\log \mathrm{CFU} / \mathrm{g}$ for Staphylococcus aureus. In contrast, the utilization of each of these technologies separately resulted in a lower decrease (e.g., only $3.0 \log \mathrm{CFU} / \mathrm{g}$ ) for both pathogens. There was no effect of $\mathrm{CP}$ on the antibacterial activity or chemical composition of EO, suggesting no EO degradation by CP. The beef jerky was inoculated with the pathogenic microorganism for processing, treated with EO, and subsequently exposed to CP treatment (Yoo et al., 2021).

The application of both EOs and CP in other food matrices and on different food-contact surfaces has also been studied (Table 1, Figs. 1 and 2). Clove, lime, and sweet basil EO and their major constituents (eugenol, D-limonene, and $\beta$-ocimene) were combined with CP (20 and $40 \mathrm{~W}, 10 \mathrm{~min}$, atmospheric RF plasma jet system) against $S$. Typhimurium, $S$. aureus, and E. coli on the chicken egg surface. Sweet basil or lime EO (15 and $20 \mu \mathrm{L} / \mathrm{mL}$, respectively) with CP (40 W) inhibited the growth of $S$. Typhimurium by $80-100 \%$, clove EO $(10 \mu \mathrm{L} / \mathrm{mL})$ and eugenol inhibited the growth of all bacteria, whereas $\beta$-ocimene and D-limonene did not inhibit the microorganisms. EOs applied individually inactivated microorganisms only with $80-140 \mu \mathrm{L} / \mathrm{mL}$, while the sole utilization of $\mathrm{CP}$ resulted in only 1-3 log CFU reductions. Microbial inactivation was dependent on the pathogenic microorganism and the EO type. For the processing, the eggs were inoculated with the pathogenic microorganisms by spray inoculation, treated with EO (in solution with methanol), and subsequently exposed to CP treatment (Matan, Nisoa, \& Matan, 
Table 1

An overview of recently conducted research on assessing the antimicrobial activity of essential oils (whole, components or micro/nano-emulsions) in combination with emerging processing technologies.

\begin{tabular}{|c|c|c|c|c|c|c|c|c|c|c|}
\hline Food Matrix & \multicolumn{2}{|c|}{$\begin{array}{l}\text { Essential oils/Individual } \\
\text { constituents/ } \\
\text { Nanoemulsions }\end{array}$} & \multicolumn{2}{|c|}{$\begin{array}{l}\text { Applied } \\
\text { concentrations }\end{array}$} & \multicolumn{2}{|c|}{$\begin{array}{l}\text { Combined } \\
\text { treatment }\end{array}$} & \multicolumn{2}{|c|}{$\begin{array}{l}\text { Target microorganism } \\
\text { (inoculation level) }\end{array}$} & Main results & References \\
\hline $\begin{array}{l}\text { Surface of chicken } \\
\text { egg }\end{array}$ & \multicolumn{2}{|c|}{$\begin{array}{l}\text { Sweet basil } \\
\text { Lime } \\
\text { Clove (and their main } \\
\text { components: } \beta \text {-ocimene, } \\
\text { D-limonene and eugenol) }\end{array}$} & \multicolumn{2}{|c|}{$5-20 \mu \mathrm{L} / \mathrm{mL}$} & \multicolumn{2}{|c|}{$\begin{array}{l}\text { Cold Plasma } \\
20 \mathrm{~W} \text { and } 40 \\
\mathrm{~W} \text { for } 10 \mathrm{~min}\end{array}$} & \multicolumn{2}{|c|}{$\begin{array}{l}\text { Salmonella Typhimurium, } \\
\text { Escherichia coli, and } \\
\text { Staphylococcus aureus ( } 6 \\
\log \mathrm{CFU} / \mathrm{g})\end{array}$} & $\begin{array}{l}\text { Concentrations of sweet basil oil of } 15 \text { and } \\
20 \mathrm{~mL} \text { and cold plasma } 40 \mathrm{~W} \text { inhibited the } \\
\text { growth of } S \text {. Typhimurium in a range of } \\
80 \%-100 \% \text {. } \\
\text { Lime oil } 20 \mathrm{~mL} \text { and plasma } 40 \mathrm{~W} \text { inhibited } \\
\text { the growth of } S \text {. Typhimurium by } 90 \% \text {. } \\
10 \mu \mathrm{L} / \mathrm{mL} \text { of clove oil or } 5 \mathrm{~mL} \text { of eugenol } \\
\text { combined with } 40 \mathrm{~W} \text { cold plasma inhibited } \\
\text { all bacterial strains tested. b-ocimene and } \\
\text { D-limonene did not show inhibitory } \\
\text { activity. }\end{array}$ & $\begin{array}{l}\text { Matan et al. } \\
(2014)\end{array}$ \\
\hline $\begin{array}{l}\text { Surfaces of food } \\
\text { container (glass } \\
\text { sheet, stainless } \\
\text { steel, and } \\
\text { plastic) }\end{array}$ & \multicolumn{2}{|c|}{$\begin{array}{l}\text { Helichrysum italicum } \\
\text { (Strawflower) }\end{array}$} & \multicolumn{2}{|c|}{$\begin{array}{l}40 \mathrm{~min}, 0.5 \mathrm{mg} / \\
\mathrm{mL}\end{array}$} & \multicolumn{2}{|c|}{$\begin{array}{l}\text { Cold Plasma } \\
1 \mathrm{~min}, 400 \mathrm{~W}\end{array}$} & \multicolumn{2}{|c|}{$\begin{array}{l}\text { S. aureus biofilm (8 log } \\
\left.\mathrm{CFU} / \mathrm{cm}^{2}\right)\end{array}$} & $\begin{array}{l}\text { Cells of } S \text {. aureus in biofilms formed on } \\
\text { stainless steel surfaces decreased by } 3.95 \\
\text { log but no viable cells were found after } 2 \\
\text { days of storage. } \\
\text { After } 0,1 \text {, and } 2 \text { days of storage, decreases } \\
\text { of } 4.17,4.24 \text { and } 6.28 \text { log were observed } \\
\text { on glass sheet biofilms, respectively. } \\
\text { After } 2 \text { days of storage } S \text {. aureus cells } \\
\text { decreased by } 7.29 \text { log units on biofilms } \\
\text { formed on plastic surfaces. }\end{array}$ & $\begin{array}{l}\text { Cui, Li, Li, } \\
\text { and Lin } \\
(2016)\end{array}$ \\
\hline Pork loin & \multicolumn{2}{|c|}{ Lemongrass } & \multicolumn{2}{|c|}{$\begin{array}{l}5 \mathrm{mg} / \mathrm{mL}, \\
30 \mathrm{~min}\end{array}$} & \multicolumn{2}{|c|}{$\begin{array}{l}\text { Cold Plasma } \\
500 \mathrm{~W}, 120 \mathrm{~s}\end{array}$} & \multicolumn{2}{|c|}{$\begin{array}{l}\text { Listeria monocytogenes (4 } \\
\log \mathrm{CFU} / \mathrm{g} \text { ) }\end{array}$} & $\begin{array}{l}\text { L. monocytogenes viable cells decreased } \\
2.80 \log \mathrm{CFU} / \mathrm{g} \text { on pork through a } \\
\text { synergistic antibacterial effect of combined } \\
\text { treatments. }\end{array}$ & $\begin{array}{l}\text { Cui, Wu, Li, } \\
\text { and Lin } \\
(2016)\end{array}$ \\
\hline Lettuce leaves & \multicolumn{2}{|l|}{ Clove } & \multicolumn{2}{|c|}{$1 \mathrm{mg} / \mathrm{mL}$} & \multicolumn{2}{|c|}{$\begin{array}{l}\text { Cold Plasma } \\
400 \mathrm{~W}, 3 \mathrm{~min}\end{array}$} & \multicolumn{2}{|c|}{$\begin{array}{l}\text { E. coli biofilm O157:H7 (6 } \\
\left.\log \mathrm{CFU} / \mathrm{cm}^{2}\right)\end{array}$} & $\begin{array}{l}\text { The combined treatment reduced counts of } \\
\text { E. coli } \mathrm{O} 157: \mathrm{H} 7 \text { by } 5.48 \log \mathrm{CFU} / \mathrm{cm}^{2} \text {. }\end{array}$ & $\begin{array}{l}\text { Cui, Ma, and } \\
\text { Lin (2016) }\end{array}$ \\
\hline Eggshells & Thyme & \multicolumn{2}{|c|}{$\begin{array}{l}0.25,0.5 \text { and } 1 \mathrm{mg} / \\
\mathrm{mL}\end{array}$} & \multicolumn{2}{|c|}{$\begin{array}{l}\text { Cold Plasma } \\
400 \mathrm{~W}, 0.5 \text { min or } 1 \\
\text { min }\end{array}$} & \multicolumn{2}{|c|}{$\begin{array}{l}S \text {. Enteritidis and } S \text {. } \\
\text { Typhimurium (8-9 log } \\
\text { CFU/mL) }\end{array}$} & \multicolumn{2}{|c|}{$\begin{array}{l}\text { The highest antibacterial activity was observed for } \\
\text { thyme oil at } 0.5 \mathrm{mg} / \mathrm{mL} \text { and cold plasma at } 400 \mathrm{~W} \\
\text { for } 1 \mathrm{~min} \text {, reaching to }<10 \mathrm{CFU} / \mathrm{egg} \text { of } S \text {. } \\
\text { Enteritidis and } S \text {. Typhimurium. }\end{array}$} & $\begin{array}{l}\text { Cui, Ma, Li, and } \\
\text { Lin (2016) }\end{array}$ \\
\hline $\begin{array}{l}\text { Chicken } \\
\text { meat and } \\
\text { duck meat }\end{array}$ & Thyme & \multicolumn{2}{|l|}{$0.25 \mathrm{mg} / \mathrm{mL}$} & \multicolumn{2}{|c|}{$\begin{array}{l}\text { Cold Plasma } \\
400 \mathrm{~W}, 4 \mathrm{~min} .\end{array}$} & \multicolumn{2}{|c|}{$\begin{array}{l}\text { S. Typhimurium (4 log } \\
\text { CFU/g) }\end{array}$} & \multicolumn{2}{|c|}{$\begin{array}{l}\text { Thyme EO and silk fibroin nanofiber (TO/SF) } \\
\text { membrane decreased counts of } S \text {. Typhimurium by } \\
1.15 \log \mathrm{CFU} / \mathrm{g} \text {. }\end{array}$} & Lin et al. (2019) \\
\hline Beef jerky & Clove & \multicolumn{2}{|l|}{$1 \%$} & \multicolumn{2}{|l|}{$\begin{array}{l}\text { Cold Plasma } \\
15 \text { min }\end{array}$} & \multicolumn{2}{|c|}{$\begin{array}{l}\text { E. coli } \mathrm{O} 157: \mathrm{H} 7 \text { and } \\
\text { S. aureus }(8 \log \mathrm{CFU} / \\
\text { g) }\end{array}$} & \multicolumn{2}{|c|}{$\begin{array}{l}\text { Application of clove essential oil and cold plasma } \\
\text { reduced } \sim 7.5 \log \mathrm{CFU} / \mathrm{g} \text { of } E \text {. coli } \mathrm{O} 157: \mathrm{H} 7 \text { and } \sim 8 \\
\log \mathrm{CFU} / \mathrm{g} \text { of } S . \text { aureus cells. }\end{array}$} & Yoo et al. (2021) \\
\hline $\begin{array}{l}\text { Lettuce } \\
\text { leaves }\end{array}$ & Oregano & $\begin{array}{l}0.010 \% \mathrm{v} / \mathrm{v}, 0.0 \\
\mathrm{v} / \mathrm{v} .0 .018 \% \mathrm{v} / \mathrm{v} \\
0.022 \% \mathrm{v} / \mathrm{v} \text { and } \\
0.025 \% \mathrm{v} / \mathrm{v}\end{array}$ & & $\begin{array}{l}\text { Ultrasound } \\
\text { (continuous } \\
\text { pulsed mode } \\
10 \mathrm{~s} \text { on } / 6 \mathrm{~s} \\
\text { on } / 5 \mathrm{~s} \text { off; a } \\
\mathrm{s} \text { on } / 8 \mathrm{~s} \text { off. } \\
\text { ( } 90 \mu \mathrm{m}, 26 \\
\text { W) }\end{array}$ & $\begin{array}{l}\text { or } \\
\text { ff; } 5 \mathrm{~s} \\
\text { d (iii) } 2 \\
\text { Hz, } 200\end{array}$ & $\begin{array}{l}\text { E. co } \\
\mathrm{CFU}\end{array}$ & $\begin{array}{l}i \mathrm{O} 157: \mathrm{H} 7(6 \log \\
\left(\mathrm{cm}^{2}\right)\end{array}$ & $\begin{array}{l}\text { Synergi } \\
\text { mode o } \\
\text { Combir } \\
\text { below } t\end{array}$ & $\begin{array}{l}\text { n was detected for continuous or pulse } \\
\text { ltrasound and } 0.025 \%(\mathrm{v} / \mathrm{v}) \text { oregano EO. } \\
\text { treatments reduced } E \text {. coli to counts } \\
\text { limit of detection. }\end{array}$ & $\begin{array}{l}\text { Millan-Sango } \\
\text { et al. (2015) }\end{array}$ \\
\hline $\begin{array}{l}\text { Lettuce } \\
\text { leaves }\end{array}$ & $\begin{array}{l}\text { Oregano } \\
\text { and thyme }\end{array}$ & $\begin{array}{l}0.010 \%, 0.014 \% \\
0.018 \%, 0.022 \% \\
0.025 \% \mathrm{v} / \mathrm{v}\end{array}$ & & $\begin{array}{l}\text { Ultrasound } \\
\text { (continuous } \\
\text { pulsed mod } \\
2 \mathrm{~s} \mathrm{on} / 8 \mathrm{~s} \mathrm{o} \\
\mathrm{kHz}, 90 \mathrm{~mm}\end{array}$ & $\begin{array}{l}\text { or } \\
(26 \\
200 \mathrm{~W})\end{array}$ & $\begin{array}{l}\text { S. en } \\
\mathrm{cm}^{2}\end{array}$ & terica (6 log CFU/ & $\begin{array}{l}\text { Pulsed } \\
\text { and ore } \\
2.95 \text { lo } \\
\text { Thyme } \\
\text { ultraso } \\
\text { to }<2 \text { l }\end{array}$ & $\begin{array}{l}\text { continuous ultrasonication ( } 2 \text { son } / 8 \mathrm{~s} \text { off }) \\
\text { ano EO }(0.018 \% \mathrm{v} / \mathrm{v}) \text { decreased } 3.08 \text { and } \\
\mathrm{CFU} / \mathrm{cm}^{2} \text { of } S \text {. enterica, respectively. } \\
\mathrm{O} \text { and continuous or pulsed } \\
\text { cation in combination reduced Salmonella } \\
\mathrm{CFU} / \mathrm{cm}^{2} .\end{array}$ & $\begin{array}{l}\text { Millan-Sango } \\
\text { et al. (2016) }\end{array}$ \\
\hline
\end{tabular}

\begin{tabular}{|c|c|c|c|c|c|}
\hline $\begin{array}{l}\text { Pomegranate } \\
\text { and orange } \\
\text { juices }\end{array}$ & Cinnamon & $\begin{array}{l}0.02 \\
\mathrm{mg} / \mathrm{mL}\end{array}$ & $\begin{array}{l}\text { Thermo- } \\
\text { ultrasound } \\
105 \mu \mathrm{m} \text {; } \\
33.31 \mathrm{WmL}^{-1} ; 30 \\
\mathrm{~min} ; 50{ }^{\circ} \mathrm{C}\end{array}$ & $\begin{array}{l}\text { S. cerevisiae (5 log CFU/ } \\
\mathrm{mL})\end{array}$ & $\begin{array}{l}\text { Combined treatments decreased } 2.52 \text { and } 2.81 \\
\mathrm{CFU} / \mathrm{mL} \text { of } S \text {. cerevisiae in pomegranate and } \\
\text { orange juices, respectively. After } 3 \text { weeks of } \\
\text { refrigerated storage }\left(5{ }^{\circ} \mathrm{C}\right), S \text {. cerevisiae counts } \\
\text { decreased } 0.68 \text { and } 1.55 \mathrm{log} \text { units in orange and } \\
\text { pomegranate juices, respectively. }\end{array}$ \\
\hline Orange juice & Cinnamon & $\begin{array}{l}650 \\
\mu \mathrm{g} / \mathrm{mL}\end{array}$ & $\begin{array}{l}\text { Thermo- } \\
\text { ultrasound } \\
24 \mathrm{kHz} ; 105 \mu \mathrm{m} \text {; } \\
33.31 \mathrm{~W} \mathrm{~mL}-1 \\
30 \mathrm{~min} ; 50{ }^{\circ} \mathrm{C}\end{array}$ & $\begin{array}{l}\text { S. cerevisiae (5 log CFU/ } \\
\mathrm{mL})\end{array}$ & $\begin{array}{l}\text { After combined treatment, S. cerevisiae decreased } \\
\text { by } 3.8 \log \mathrm{CFU} / \mathrm{mL} \text {. }\end{array}$ \\
\hline Milk & Cinnamon & $\begin{array}{l}0.312 \\
\mu \mathrm{L} / \mathrm{mL}\end{array}$ & $\begin{array}{l}\text { Ultrasound } \\
24 \mathrm{kHz} 400 \mathrm{~W} \\
\text { power for } 15 \mathrm{~min}\end{array}$ & $\begin{array}{l}\text { L. monocytogenes and } S \text {. } \\
\text { Typhimurium (7 log } \\
\text { CFU/g) }\end{array}$ & $\begin{array}{l}\text { Combined treatment decreased } L \text {. monocytogenes } \\
\text { counts by } 4.3 \text { and } 4.5 \text { log cycles in low-fat milk } \\
\text { and high-fat milk, respectively. } S \text {. Typhimurium } \\
\text { reduced } 2.7 \text { and } 3.8 \text { log units in low-fat milk and } \\
\text { high-fat milk, respectively. }\end{array}$ \\
\hline
\end{tabular}

Sánchez-Rubio, TaboadaRodríguez, Cava-Roda, López-Molina, \& Marínniesta, (2016)

Sánchez-Rubio et al. (2018)

Mortazavi and Aliakbarlu (2019)

Zhang et al. (2020)

(continued on next page) 
Table 1 (continued)

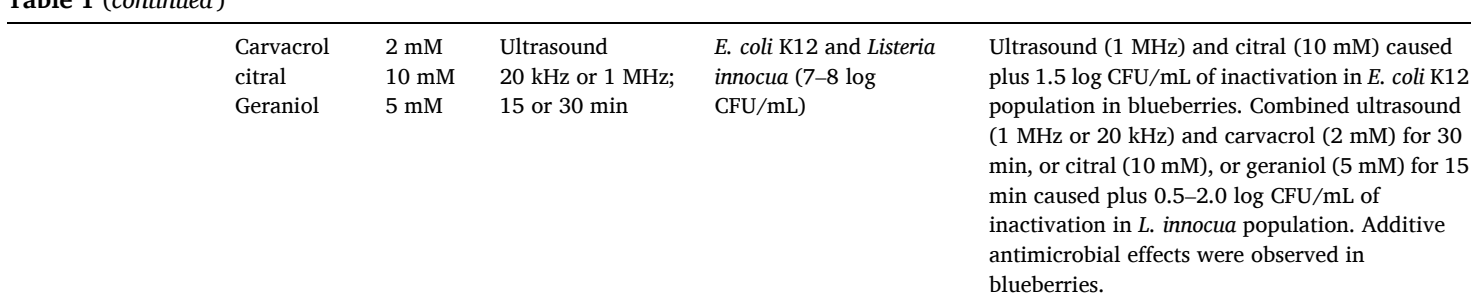

\begin{tabular}{|c|c|c|c|c|}
\hline Blueberries & Carvacrol & $2 \mathrm{mM}$ & $\begin{array}{l}\text { Ultrasound } \\
20 \mathrm{kHz} \text { or } 1 \\
\mathrm{MHz} \text { at } 20^{\circ} \mathrm{C} \\
\text { por } 10 \mathrm{~min}\end{array}$ & $\begin{array}{l}\text { L. innocua (5 log CFU/ } \\
\text { g) }\end{array}$ \\
\hline Maize & Cananga odorata (Parfum tree) & $0-5 \mathrm{mg} / \mathrm{g}$ & $\begin{array}{l}\text { Irradiation } \\
\text { (Gamma ray) } \\
0-10 \mathrm{kGy}\end{array}$ & $\begin{array}{l}\text { Fusarium graminearum } \\
\left(10^{6} \text { spores } / \mathrm{mL}\right)\end{array}$ \\
\hline $\begin{array}{l}\text { Fish Silver } \\
\text { carp }\end{array}$ & Rosemary & $0,5 \%, \mathrm{v} / \mathrm{v}$ & $\begin{array}{l}\text { Irradiation } \\
\text { (Gamma ray) } 1 \text {, } \\
3 \text {, and } 5 \mathrm{kGy}\end{array}$ & $\begin{array}{l}\text { Psychrophilic bacteria, } \\
\text { bacterial count, and } \\
\text { Lactic }\end{array}$ \\
\hline Rice & $\begin{array}{l}\text { Thyme (Thymus vulgaris), Oregano } \\
\text { (Origanum compactum; Moroccan } \\
\text { oregano), pepper- mint (Mentha } \\
\text { piperita), and tea tree (Melaleuca } \\
\text { alternifolia) }\end{array}$ & $\begin{array}{l}0.13 \text { and } \\
0.19 \% \mathrm{w} / \\
\mathrm{w}\end{array}$ & $\begin{array}{l}\text { Irradiation } \\
\text { (Gamma ray) } \\
750 \mathrm{~Gy}\end{array}$ & $\begin{array}{l}\text { Aspergillus parasiticus, } \\
\text { Aspergillus flavus, } \\
\text { Aspergillus niger, and } \\
\text { Penicillium } \\
\text { chrysogenum (3 log } \\
\text { CFU/g) }\end{array}$ \\
\hline Rice & $\begin{array}{l}\text { Nanoemulsion of oregano and } \\
\text { thyme }\end{array}$ & $\begin{array}{l}0.25 \text {, } \\
0.50 \text { and } \\
0.75 \% \mathrm{v} / \\
\mathrm{v}\end{array}$ & $\begin{array}{l}\text { Irradiation } \\
\text { (Gamma ray) } \\
750 \mathrm{~Gy}\end{array}$ & $\begin{array}{l}\text { A. flavus, A. parasiticus, } \\
\text { A. niger, and } P \text {. } \\
\text { chrysogenum }\left(10^{8}\right. \\
\text { conidia/mL) }\end{array}$ \\
\hline
\end{tabular}

\section{$20 \mathrm{kHz}$ or $1 \mathrm{MHz}$ ultrasound (treatments Zhang et al. in combination with $2 \mathrm{mM}$ carvacrol (2021) reduced $L$. innocua counts on the fruit} surface by $\sim 2$ and $3 \log \mathrm{CFU} / \mathrm{g}$, respectively.

Combined treatment reduced fungal growth and levels of mycotoxins to below the detection limit in maize kernels. Combined treatment of rosemary EO and irradiation at 1,3 , and $5 \mathrm{kGy}$ reduced the psychrophilic bacteria, total bacterial count

During the 8 weeks of storage the combined treatment of $0.19 \% \mathrm{w} / \mathrm{w}$ oregano-thyme mixture and irradiation reduced $70-80 \%$ of the fungal growth.

Addition of 7.5\% cellulose nanocrystal (CNC) into methylcellulose (MC) with $0.50-0.75 \%$ EO and utilization of high pressure (103 MPa) created a nanoemulsion with in vitro antifungal activity against $A$. flavus, $A$. parasiticus, $A$. niger and $P$. chrysogenum. Tests in situ with the MC/CNC added bioactive films added with thyme and oregano emulsion resulted in 2-log decrease in the fungal growth in the rice during storage ( 8 weeks, $28^{\circ} \mathrm{C}$ ).

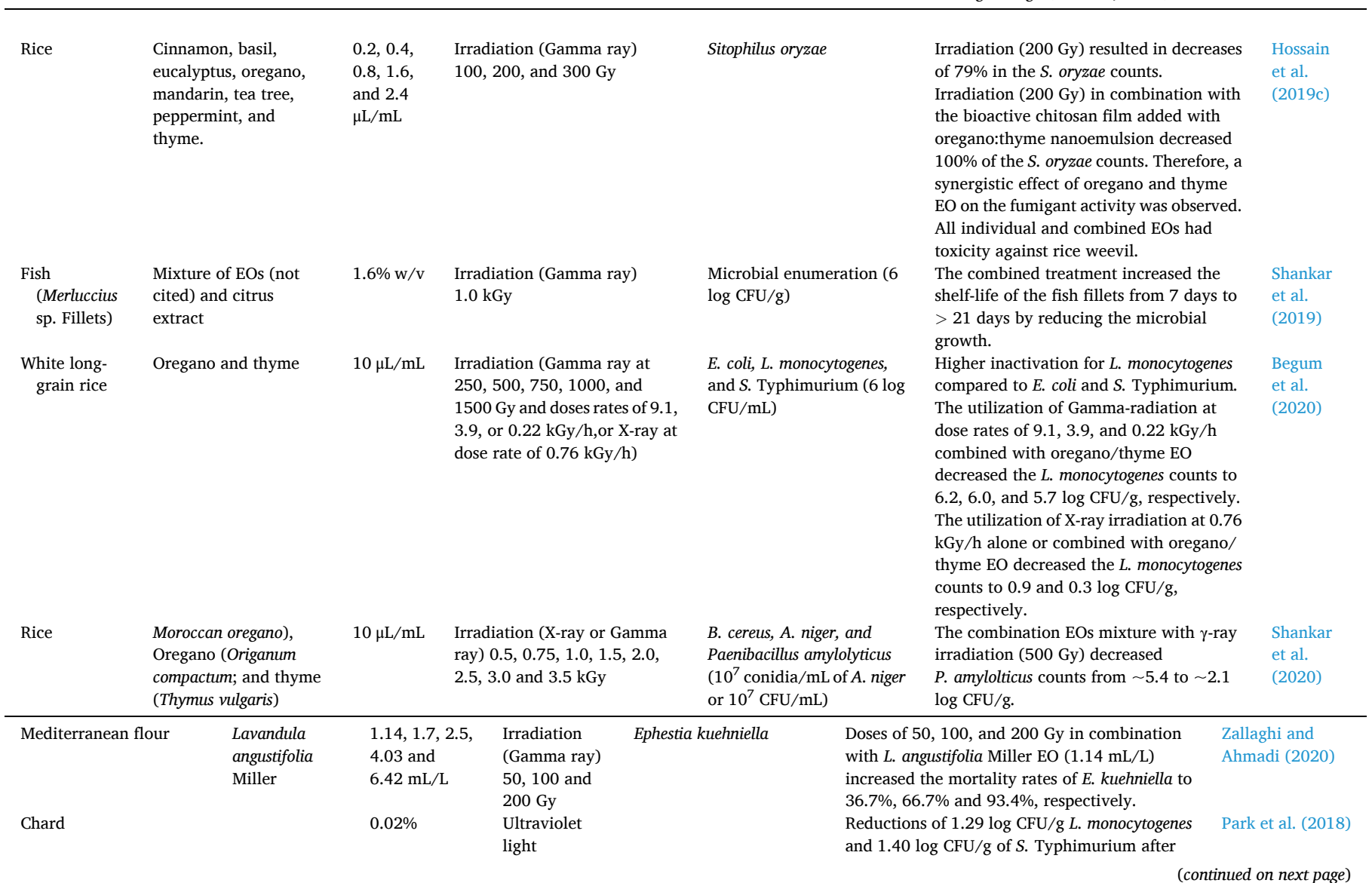


Table 1 (continued)

\begin{tabular}{|c|c|c|c|c|c|c|c|c|c|}
\hline & & \multicolumn{3}{|l|}{$\begin{array}{l}\text { Emulsions of } \\
\text { cinnamon } \\
\text { bark }\end{array}$} & $\begin{array}{l}1.2 \mathrm{~kJ} / \mathrm{m}^{2}, 2 \\
\min \end{array}$ & $\begin{array}{l}\text { L. monocytogenes and } S \text {. } \\
\text { Typhimurium }(7-8 \log \\
\text { CFU/g) }\end{array}$ & \multicolumn{2}{|c|}{$\begin{array}{l}\text { combined treatment. On the red chard surface } \\
\text { the membranes of both pathogens were } \\
\text { observed to be damaged. In addition, the } \\
\text { reductions in the microbial counts were kept } \\
\text { during storage and sensory analysis } \\
\text { demonstrated that the combined treatment had } \\
\text { no influence on the red chard quality. Additive } \\
\text { antimicrobial effects were observed. }\end{array}$} & \\
\hline \multicolumn{2}{|c|}{$\begin{array}{l}\text { Orange-tangerine and } \\
\text { orange-banana- } \\
\text { mango-kiwi- } \\
\text { strawberry juices }\end{array}$} & $\begin{array}{l}\text { Emulsions of } \\
\text { citral }\end{array}$ & \multicolumn{2}{|l|}{$\begin{array}{l}300-400 \mu \mathrm{g} / \\
\mathrm{mL}\end{array}$} & $\begin{array}{l}\text { Ultraviolet } \\
\text { light } \\
0-390 \mathrm{~mJ} / \\
\mathrm{cm}^{2}\end{array}$ & $\begin{array}{l}\text { E. coli, Lactobacillus } \\
\text { plantarum and } \\
\text { Saccharomyces cerevisia }\end{array}$ & \multicolumn{2}{|c|}{$\begin{array}{l}\text { Reductions by at least } 5 \log \mathrm{CFU} / \mathrm{g} \text { of } \\
\text { L. plantarum, E. coli, and } S \text {. cerevisiae after } \\
\text { combined treatment. The combined effect was } \\
\text { considered synergistic for } S \text {. cerevisiae and } \\
\text { additive for E. coli }\end{array}$} & $\begin{array}{l}\text { Ferrario et al. } \\
(2020)\end{array}$ \\
\hline \multicolumn{2}{|l|}{ Stainless steel } & Clove & $1.2 \mathrm{mg} / \mathrm{mL}$ & & $\begin{array}{l}\text { Ultraviolet } \\
\text { light } \\
76.41 \mathrm{~mJ} / \\
\mathrm{cm}^{2}\end{array}$ & $\begin{array}{l}\text { S. Typhimurium } \\
\text { biofilms ( } 8 \log \text { CFU/ } \\
\left.\mathrm{cm}^{2}\right)\end{array}$ & \multicolumn{2}{|c|}{$\begin{array}{l}\text { The combined treatment of } 76.41 \mathrm{~mJ} / \mathrm{cm}^{2} \text { of } \\
\text { UV-C and } 1.2 \mathrm{mg} / \mathrm{mL} \text { of clove EO resulted in a } \\
\text { complete reduction in the bacteria on biofilms } \\
\left(6.8 \log \mathrm{CFU} / \mathrm{cm}^{2}\right) \text {. }\end{array}$} & $\begin{array}{l}\text { Silva-Espinoza } \\
\text { et al. (2020) }\end{array}$ \\
\hline \multicolumn{2}{|c|}{ Dried persimmon fruits } & Clove & $1.56 \% \mathrm{v} / \mathrm{v}$ & & $\begin{array}{l}\text { Ultraviolet } \\
\text { light } \\
0.6-12.0 \mathrm{~kJ} / \\
\mathrm{m}^{2}\end{array}$ & $\begin{array}{l}\text { Rhizopus oryzae and } \\
\text { A. niger }) \\
\left(10^{6} \text { spores } / \mathrm{mL}\right)\end{array}$ & \multicolumn{2}{|c|}{$\begin{array}{l}\text { The combination of clove oil and UV-C reduced } \\
0.68 \text { and } 0.64 \log \mathrm{cfu} / \mathrm{cm}^{2} \text { for } A \text {. niger and } \\
R \text {. oryzae, respectively. }\end{array}$} & $\begin{array}{l}\text { Vurmaz and } \\
\text { Gündüz (2020) }\end{array}$ \\
\hline $\begin{array}{l}\text { Green } \\
\text { beans }\end{array}$ & \multicolumn{2}{|c|}{ Nanoemulsion of mandarin } & 2 wt $\%$ & \multicolumn{2}{|c|}{$\begin{array}{l}\text { High hydrostatic } \\
\text { processing (HHP) } \\
5 \text { min and } 400 \mathrm{MPa} \text { and } \\
\text { Pulsed light (PL) } 1.2 \times \\
10^{5} \mathrm{~J} / \mathrm{m}^{2}\end{array}$} & $\begin{array}{l}\text { L. innocua }(7 \log \\
\text { CFU/g) }\end{array}$ & \multicolumn{2}{|c|}{$\begin{array}{l}\text { The utilization of HHP or PL combined with } \\
\text { modified chitosan coating containing a } \\
\text { nanoemulsion of mandarin EO reduced } L \text {. innocua } \\
\text { counts in } 4 \text { and } 2 \text { log cycles, respectively. }\end{array}$} & $\begin{array}{l}\text { Donsì et al. } \\
\text { (2015) }\end{array}$ \\
\hline $\begin{array}{l}\text { Guava and } \\
\text { mango } \\
\text { juices }\end{array}$ & \multicolumn{2}{|c|}{$\begin{array}{l}\text { Nanoemulsions of Mentha } \\
\text { piperita L. (n-MPEO) }\end{array}$} & $\begin{array}{l}0.16 \text {, } \\
0.31 \text { and } \\
0.63 \mu \mathrm{L} / \\
\mathrm{mL}\end{array}$ & $\begin{array}{l}\text { High } \\
\text { proce } \\
150 \text {, } \\
\text { for } 1\end{array}$ & $\begin{array}{l}\text { hydrostatic } \\
200 \text {, and } 300 \mathrm{MPa} \\
5 \mathrm{~min}\end{array}$ & $\begin{array}{l}\text { Escherichia coli } \\
\text { O157:H7 (7 log } \\
\text { CFU/mL) }\end{array}$ & \multicolumn{2}{|c|}{$\begin{array}{l}\text { Decreases of } 5 \text { logs cycles when n-MPEO and PEF } \\
\text { were combined. }\end{array}$} & $\begin{array}{l}\text { Carvalho et al. } \\
\text { (2018) }\end{array}$ \\
\hline $\begin{array}{l}\text { Fresh } \\
\quad \text { ground } \\
\text { Beef }\end{array}$ & \multicolumn{2}{|c|}{$\begin{array}{l}\text { Melissa officinalis leaf } \\
\text { (MoEOs)/citral, geraniol, } \\
\beta \text {-caryophyllene (CCs) }\end{array}$} & $0.5 \mathrm{~mL}$ & $\begin{array}{l}\text { High } \\
\text { proce } \\
4{ }^{\circ} \mathrm{C} \text {, } \\
400\end{array}$ & $\begin{array}{l}\text { hydrostatic } \\
\text {, and } 300,350 \text {, and } \\
\mathrm{MPa}\end{array}$ & $\begin{array}{l}\text { E. } \operatorname{coli}(7 \log \\
\mathrm{CFU} / \mathrm{g})\end{array}$ & \multicolumn{2}{|c|}{$\begin{array}{l}\text { Decreases of } 5 \text { log CFU/g after combined } \\
\text { treatment of CCs, MoEOs or MIX (a reconstituted } \\
\text { mixture of } 1 / 3 \text { geraniol, } 1 / 3 \text { citral, and } 1 / 3 \\
\beta \text {-caryophyllene [weight basis]) and pressure. } \\
\text { Decreases of } 3-6 \log \text { CFU/g of } E \text {. coli after } \\
\text { combined treatment of } 1.0 \% \text { geraniol, } 1.0 \% \\
\text { citral, } 1.0 \% \mathrm{MIX} \text {, and } 1.0 \% \text { MoEOs with } 350 \text { and } \\
400 \mathrm{MPa} \text {. }\end{array}$} & $\begin{array}{l}\text { Chien, Sheen, S., } \\
\text { Sommers, C., \& } \\
\text { Sheen (2019) }\end{array}$ \\
\hline $\begin{array}{l}\text { Mango and } \\
\text { guava } \\
\text { juices }\end{array}$ & \multicolumn{2}{|c|}{$\begin{array}{l}\text { Nanoemulsions of Mentha } \\
\text { piperita L. (n-MPEO) }\end{array}$} & $\begin{array}{l}0.16 \text {, } \\
0.31 \text { and } \\
0.63 \mu \mathrm{L} / \\
\mathrm{mL}\end{array}$ & $\begin{array}{l}\text { Pulse } \\
\text { (PEF } \\
30 \mathrm{k}\end{array}$ & $\begin{array}{l}\text { ed electric fields } \\
(150 \mu \mathrm{s} ; 20,25 \\
\mathrm{V} / \mathrm{cm})\end{array}$ & $\begin{array}{l}\text { Escherichia coli } \\
\text { O157:H7 (7 log } \\
\text { CFU/mL) }\end{array}$ & \multicolumn{2}{|c|}{$\begin{array}{l}\text { Reductions of } 5 \text { logs cycles with n-MPEO and PEF } \\
\text { in combination. }\end{array}$} & $\begin{array}{l}\text { Carvalho et al. } \\
\text { (2018) }\end{array}$ \\
\hline Apple juice & \multicolumn{2}{|l|}{ Citral } & $\begin{array}{l}0.7 \mu \mathrm{L} / \\
\mathrm{mL}\end{array}$ & \multicolumn{2}{|c|}{$\begin{array}{l}\text { Pulsed electric fields } \\
150 \mu \mathrm{s}, 30 \mathrm{kV}\end{array}$} & $\begin{array}{l}\text { E. coli } \mathrm{O} 157: \mathrm{H7} \\
(7 \log \mathrm{CFU} / \mathrm{mL})\end{array}$ & \multicolumn{2}{|c|}{$\begin{array}{l}\text { Reductions of } 5 \text { logs cycles with } 0.1 \mu \mathrm{L} / \mathrm{mL} \text { of } \\
\text { citral and PEF }(150 \mu \mathrm{s}, 30 \mathrm{kV}) \text {. }\end{array}$} & $\begin{array}{l}\text { Pagán et al. } \\
\text { (2018) }\end{array}$ \\
\hline Chicken & \multicolumn{2}{|c|}{ Oregano } & $62.5 \mu \mathrm{g} / \mathrm{mL}$ & \multicolumn{2}{|r|}{$\begin{array}{l}\text { Pulsed electric } \\
\text { fields } 1-20 \\
\mathrm{kV} / \mathrm{cm}, 1 \mathrm{~Hz} \\
20 \mu \text { s length }\end{array}$} & \multicolumn{2}{|c|}{$\begin{array}{l}\text { Campylobacter jejuni (7 log } \\
\text { CFU/mL) }\end{array}$} & $\begin{array}{l}\text { Reductions }(1.5 \log \mathrm{CFU} / \mathrm{g}) \text { when } 62.5 \\
\mu \mathrm{g} / \mathrm{mL} \text { of oregano and PEF }(1 \mathrm{kV} / \mathrm{cm}, 1 \\
\mathrm{Hz}, 20 \mu \mathrm{s}) \text { were used in combination. }\end{array}$ & $\begin{array}{l}\text { Clemente et al. } \\
(2020)\end{array}$ \\
\hline Cucumber & \multicolumn{2}{|c|}{$\begin{array}{l}\text { Nanoemulsion of } \\
\text { carvacrol }\end{array}$} & $2 \% \mathrm{w} / \mathrm{w}$ & \multicolumn{2}{|r|}{$\begin{array}{l}\text { Pulsed light } \\
\text { (PL) } 4,8 \text {, and } \\
12 \mathrm{~J} / \mathrm{cm}^{2}\end{array}$} & \multicolumn{2}{|c|}{ E. coli ATCC 26 (7 log CFU/g) } & $\begin{array}{l}\text { The combined treatment with the } \\
\text { antimicrobial coating and } 12 \mathrm{~J} / \mathrm{cm}^{2} \text { of } \\
\text { PL had a strong synergistic effect, with } \\
>5 \text { log cycle decrease. }\end{array}$ & $\begin{array}{l}\text { Taştan et al. } \\
\text { (2017) }\end{array}$ \\
\hline Salsa & $\begin{array}{l}\text { Carvon } \\
\text { thymol }\end{array}$ & $\begin{array}{l}\text { eugenol, } \\
\text { and citral }\end{array}$ & $1 \mathrm{mM}$ & & $\begin{array}{l}\text { Ohmic heating } \\
60 \mathrm{~s} \text { and } 38 \mathrm{~s} \\
1 \mathrm{mHz}, 10 \\
\mathrm{MHz}, 5 \mathrm{~V}\end{array}$ & $\begin{array}{l}\text { L. monocytogenes }(10 \\
\mathrm{CFU} / \mathrm{g}), \text { E. coli } \mathrm{O} 157 \\
\left.\text { and } 10^{7} \mathrm{CFU} / \mathrm{g}\right) \text { and } \\
\text { Typhimurium }\left(10^{6} \text { a }\right. \\
\text { CFU/g) }\end{array}$ & $\begin{array}{l}\text { and } 10^{6} \\
\text { H7 }\left(10^{6}\right. \\
10^{7}\end{array}$ & $\begin{array}{l}\text { Ohmic and thymol combined treatment } \\
\text { resulted in the greatest inactivation of } \\
\text { bacterial pathogens. Decreases of } 4.8 \text {, } \\
4.3 \text {, and } 5.7 \text { log CFU/g for } E \text {. coli O157: } \\
\text { H7, L. monocytogenes, and } S \text {. } \\
\text { Typhimurium were observed, } \\
\text { respectively. }\end{array}$ & $\begin{array}{l}\text { Kim and Kang } \\
\text { (2017a) }\end{array}$ \\
\hline Salsa & Purifie & carvacrol & $1.3 \mathrm{mM}$ & & $\begin{array}{l}\text { Ohmic heating } \\
60,80,90 \text { and } \\
100 \mathrm{~s}, 60 \mathrm{~Hz} \text {, } \\
12.1 \mathrm{Vrms} / \mathrm{cm}\end{array}$ & $\begin{array}{l}\text { S. Typhimurium and } \\
\log \text { CFU/mL), and } \\
\text { L. monocytogenes } \\
(6 \log \text { CFU/mL) }\end{array}$ & E. $\operatorname{coli}(7$ & $\begin{array}{l}\text { Using ohmic heating, the inactivation } \\
\text { of all pathogens ( }>5 \log \text { reduction) was } \\
\text { achieved with } 75 \mathrm{~s} \text {. With the combined } \\
\text { treatment the inactivation was } \\
\text { achieved with only } 50 \mathrm{~s} \text {. }\end{array}$ & $\begin{array}{l}\text { Kim and Kang } \\
\text { (2017b) }\end{array}$ \\
\hline $\begin{array}{l}\text { Fish } \\
\qquad \text { (Merluccius } \\
\text { sp. Fillets) }\end{array}$ & $\begin{array}{l}\text { Mixtur } \\
\text { cited) } \\
\text { extract }\end{array}$ & $\begin{array}{l}\text { of EOs (not } \\
\text { d citrus }\end{array}$ & $1.6 \% \mathrm{w} / \mathrm{v}$ & & $\begin{array}{l}\text { Ozone, } 10 \\
\text { ppm, } 15 \text { min }\end{array}$ & $\begin{array}{l}\text { Microbial enumerati } \\
\mathrm{CFU} / \mathrm{g})\end{array}$ & n $(3 \log$ & $\begin{array}{l}\text { The combined treatment increased the } \\
\text { shelf-life of the fish fillets from } 7 \text { days } \\
\text { to }>21 \text { days by reducing the microbial } \\
\text { growth. }\end{array}$ & $\begin{array}{l}\text { Shankar et al. } \\
\text { (2019) }\end{array}$ \\
\hline Lettuce & $\begin{array}{l}\text { Carvac } \\
\text { oil, oli } \\
\text { and Qu }\end{array}$ & $\begin{array}{l}\text { l, oregano } \\
\text { extract, } \\
\text { laja saponin }\end{array}$ & $\begin{array}{l}0.1 \% \text { for oregano } \\
0.1-0.5 \% \text { for } \\
\text { carvacrol, } 1 \text { and } \\
\text { for olive extract, } \\
0.0001 \% \text { for sapc }\end{array}$ & $\begin{array}{l}\text { oil, } \\
5 \% \\
\text { and } \\
\text { onin }\end{array}$ & $\begin{array}{l}\text { Ozone, } 60,90 \\
\text { and } 120 \mathrm{~min}\end{array}$ & $\begin{array}{l}\text { Salmonella enterica s } \\
\text { Newport }\end{array}$ & rotype & $\begin{array}{l}\text { The combined treatments of ozone and } \\
0.5 \% \text { oregano oil and O3 and carvacrol } \\
(0.1,0.3 \text { or } 0.5 \%) \text { resulted in reductions } \\
\text { below the limit of detection ( } 10 \mathrm{CFU} / \mathrm{g} \text { ) } \\
\text { The combined treatments did not alter } \\
\text { the visual appearance of the products. }\end{array}$ & $\begin{array}{l}\text { Kumar and } \\
\text { Ravishankar } \\
\text { (2019) }\end{array}$ \\
\hline
\end{tabular}


2014). In another study, the combined utilization of thyme EO (0.25-1 $\mathrm{mg} / \mathrm{mL}$ ) and $\mathrm{CP}$ ( $400 \mathrm{~W}, 0.5$ or $1 \mathrm{~min}$, cold nitrogen plasma) limited the growth of $S$. Typhimurium and $S$. Enteritidis on eggs, resulting in counts below the undetectable level ( $<10 \mathrm{CFU} / \mathrm{egg}$ ) in the course of 14 storage days at 4,12 , and $25{ }^{\circ} \mathrm{C}$. In this way, the EO was maintained inside the product and limited microbial growth during storage. On the other hand, the utilization of thyme EO or CP separately and for a short time resulted in low antimicrobial activity against pathogens. The results were dependent on $\mathrm{CP}$ processing parameters and EO concentration, that is, higher CP power and EO concentrations resulted in higher inactivation rates. For the processing, the eggs were inoculated with the pathogenic microorganisms by using a bacterial suspension, treated with EO, and subsequently exposed to CP treatment (Cui, Ma, Li, \& Lin, 2016). In another study, combined treatment of clove EO $(1 \mathrm{mg} / \mathrm{mL})$ and $\mathrm{CP}$ (400 W, $3 \mathrm{~min}$, cold nitrogen plasma generating device) reduced E. coli $\mathrm{O} 157: \mathrm{H7}\left(5.48 \mathrm{log} \mathrm{CFU} / \mathrm{cm}^{2}\right.$ ) biofilms. However, a mildly negative effect on lettuce quality was observed. Conversely, the utilization of low-intensity CP or low EO concentrations individually had no significant effect on the biofilm. For the processing, the lettuce leaves were inoculated with the pathogenic microorganisms by immersion in a solution with the pathogens, treated with EO, and subsequently exposed to CP treatment (Cui, Ma, \& Lin, 2016).

On food containers surfaces (stainless steel, plastic, and glass sheet), reductions in $S$. aureus biofilm from 3.95 to $7.29 \operatorname{logs} \mathrm{CFU} / \mathrm{cm}^{2}$ were observed after combining Helichrysum italicum EO (40 min, $0.5 \mathrm{mg} / \mathrm{mL}$ ) with CP (1 min, $400 \mathrm{~W}$, cold nitrogen plasma). The utilization of the technologies separately resulted in reductions lower than 2 logs CFU/ $\mathrm{cm}^{2}$. For the processing, the surfaces with the biofilms were exposed to $\mathrm{CP}$ treatment and treated subsequently with the EO (Cui, Li, Li, \& Lin, 2016).

The results suggested that the combination of EOs and CP might be a promising alternative to successfully removing biofilms on different food-contact surfaces and inactivating food pathogens in different food products. The combined application of $\mathrm{CP}$ and EOs resulted in more severe damage to the cell membrane, increased membrane permeability, and higher leakage of intracellular materials than the application of the technologies separately (Cui, Wu, et al., 2016; Yoo et al., 2021). It was postulated that EO might be inserted into the phospholipid bilayer of the microbial cells, thereby promoting their destabilization and pores' formation. CP could then increase the size and number of pores in the cell membranes, resulting in higher permeability (Cui, Ma, \& Lin, 2016). Furthermore, EO may decrease the resistance of pathogenic bacteria and assist' CP to achieve higher inactivation rates (Yoo et al., 2021). When EO was incorporated in nanofibers, CP's significant action on the surface of the structure increased the release of $\mathrm{EO}$ and resulted in a more significant antibacterial effect (Lin et al., 2019).

Based on the results of these studies, we can conclude that CP may have a synergistic effect in combination with EO (lemongrass, thyme, clove, lime, sweet basil, and Helichrysum italicum) for the inactivation of foodborne pathogens (Salmonella, S. aureus, L. monocytogenes, and E. coli) on food surfaces (egg), in food products (meat and vegetables), and on food containers (glass sheet, stainless steel, and plastic). Combining technologies can help overcome certain limitations of CP while increasing the inactivation of Gram-positive bacteria and maintaining the sensory characteristics of high-fat products, such as meat. However, CP's effectiveness in the inactivation of pathogens in foods that require penetration to access the pathogens, such as chopped and ground meat, calls for further evaluation, as CP has low penetration capacity, which, nevertheless, can be improved by applying it together with EO.

\subsection{Essential oils and ultrasound}

US (ultrasound) consists of pressure waves with frequencies of at least $20 \mathrm{kHz}$, which promote a rapid formation, development, and breakdown of bubbles, resulting in cavitation. Cavitation leads to extremely high localized pressures (50 MPa) and temperatures (e.g. $5500{ }^{\circ} \mathrm{C}$ ) (Sánchez-Rubio, Taboada-Rodríguez, Cava-Roda, López-Gómez, \& Marín-Iniesta, 2016). The antimicrobial effect of US is associated with the shearing and breaking of the cell membranes by cavitation, hotspot formation, damages to DNA, and production of free radicals. The shear forces generated during the bubble implosion led to cell breakdown causing cell lysis. The treatment's antimicrobial capacity is dependent on the US processing parameters, such as type of US waves, processing time, frequency, pulse mode, pulse duration, and power (Guimarães et al., 2019).

In many cases, the US is recognized as a green technology that can offer advantages such as reducing processing time, efficiency in microbial inactivation, and low energy requirements compared to conventional thermal processing (Table 2). However, the US's application in food products may result in alterations in their physical and chemical characteristics, mainly due to the high temperatures and pressures involved. The radicals formed during cavitation may exert an impact on the oxidation of lipids, change the sensory profile, denature proteins, and reduce the concentrations of bioactive compounds (phenolic compounds and ascorbic acid) (Bhargava, Mor, Kumar, \& Sharanagat, 2020). Furthermore, the US, applied individually, may not be highly effective in inactivating bacteria on food. Therefore, US's use in combined processes with EOs has been recommended (Millan-Sango et al., 2016).

EOs and their ICs combined with the US have been used to increase food quality and safety, mainly of plant-based products (Table 1, Figs. 1 and 2). Millan-Sango, McElhatton, and Valdramidis (2015) reported that concentrations of oregano EO $(0.018,0.022$, and $0.025 \% \mathrm{v} / \mathrm{v})$, combined with the US, reduced $E$. coli below the limit of detection in lettuce leaves. Also, $0.025 \%(\mathrm{v} / \mathrm{v})$ was the concentration that caused the most significant synergistic effect. Furthermore, the utilization of continuous and pulsed modes in US treatment improved the combined treatment's antimicrobial effect. In another study, reducing S. enterica Abony (6 logs $\mathrm{CFU} / \mathrm{cm}^{2}$ ) counts below the limit of lettuce leaves' detection was observed when oregano or thyme EO $(0.025 \% \mathrm{v} / \mathrm{v})$ was combined with pulsed or continuous US. On the other hand, the individual application of either US or EO resulted in less than $1 \log \mathrm{CFU} /$ sample inactivation. EO was diluted in water for the processing, added to the lettuce leaves previously inoculated with pathogens, and the products were subjected to US treatment. The treatment time was found to be the most influential parameter as compared with system configuration (e.g., pulsed $v s$. continuous). This study demonstrated that the degree of EO concentration is an important parameter, as concentrations lower than $0.018 \%$ in the combined treatment resulted in no synergistic effect with the US (Millan-Sango et al., 2016).

A combined treatment of thermo-US $(105 \mu \mathrm{m} ; 24 \mathrm{KHz} ; 30 \mathrm{~min} ; 33.31$ $\left.\mathrm{WmL}^{-1} ; 50{ }^{\circ} \mathrm{C}\right)$ with cinnamon $(0.02 \mathrm{mg} / \mathrm{mL})$ reduced the initial Saccharomyces cerevisiae population by 2.81 and $2.52 \log \mathrm{CFU} / \mathrm{mL}$ in pomegranate and orange juice samples, respectively, and by 0.68 and $1.55 \log \mathrm{CFU} / \mathrm{mL}$ during storage. EOs were added to the fruit juices inoculated with $S$. cerevisiae; the products were subsequently subjected to thermo-US. The degree of inactivation of $S$. cerevisiae was dependent on the bioactive components (tannins and anthocyanins) and $\mathrm{pH}$ of the products (Sánchez-Rubio et al., 2016). In another study, a decrease of $3.8 \log \mathrm{CFU} / \mathrm{mL}$ of $S$. cerevisiae was observed in orange juice after a combined treatment of cinnamon leaf EO $(650 \mu \mathrm{g} / \mathrm{mL})$ and thermo-US $\left(105 \mu \mathrm{m} ; 24 \mathrm{KHz} ; 33.31 \mathrm{WmL}^{-1} ; 50{ }^{\circ} \mathrm{C} ; 30 \mathrm{~min}\right)$. EOs were diluted in the fruit juices inoculated with $S$. cerevisiae; the products were subsequently subjected to thermo-US. The authors reported that the treatment's antimicrobial effectiveness was dependent on US wave amplitude, processing temperature, treatment time, and type and concentration of the EO (Sánchez-Rubio, Taboada-Rodríguez, Cava-Roda, López-Molina, \& Marín-Iniesta, 2018).

Synergistic inactivation of E. coli K12 and L. innocua was observed with increased reductions by $0.5-2.0 \mathrm{log}$ with treatment with citral (10 $\mathrm{mM})$, carvacrol $(2 \mathrm{mM})$, or geraniol $(5 \mathrm{mM})$, and both high and low- 
Table 2

Advantages and limitations of the emerging technologies.

\begin{tabular}{|c|c|c|c|c|c|c|c|c|c|}
\hline Parameter & Cold Plasma & Ultrasound & Irradiation & Ultraviolet light & $\begin{array}{l}\text { High Hydrostatic } \\
\text { Pressure }\end{array}$ & Pulsed electric fields & Pulsed light & Ohmic heating & Ozone \\
\hline $\begin{array}{l}\text { Effect on } \\
\text { microbial } \\
\text { population }\end{array}$ & $\begin{array}{l}\text { Inactivation in } \\
\text { irregular or bulky } \\
\text { surface is difficult } \\
\text { and dependent on } \\
\text { the process } \\
\text { parameters }\end{array}$ & $\begin{array}{l}\text { Inactivation is } \\
\text { dependent on the } \\
\text { used power } \\
\text { Permanent or non- } \\
\text { permanent } \\
\text { acquisition of } \\
\text { microbial resistance } \\
\text { has been } \\
\text { demonstrated }\end{array}$ & $\begin{array}{l}\text { Inactivation is } \\
\text { dependent on the } \\
\text { doses }\end{array}$ & $\begin{array}{l}\text { Low penetration } \\
\text { capacity Permanent } \\
\text { or non-permanent } \\
\text { acquisition of } \\
\text { microbial resistance } \\
\text { has been } \\
\text { demonstrated }\end{array}$ & $\begin{array}{l}\text { Inactivation is } \\
\text { dependent on the } \\
\text { treatment intensity } \\
\text { (pressure, time) } \\
\text { Permanent or non- } \\
\text { permanent } \\
\text { acquisition of } \\
\text { microbial resistance } \\
\text { has been } \\
\text { demonstrated }\end{array}$ & $\begin{array}{l}\text { Inactivation is } \\
\text { dependent on the } \\
\text { treatment intensity } \\
\text { (electric field, pulse } \\
\text { energy) } \\
\text { Permanent or non- } \\
\text { permanent } \\
\text { acquisition of } \\
\text { microbial resistance } \\
\text { has been } \\
\text { demonstrated }\end{array}$ & $\begin{array}{l}\text { Penetration capacity } \\
\text { is dependent on the } \\
\text { pulsed light High } \\
\text { protein and oily } \\
\text { foods protect } \\
\text { microorganisms }\end{array}$ & $\begin{array}{l}\text { Electrical } \\
\text { conductivity of } \\
\text { foods may } \\
\text { protect } \\
\text { microorganism } \\
\text { High fat } \\
\text { products may } \\
\text { have cold zones }\end{array}$ & $\begin{array}{l}\text { Need high ozone } \\
\text { concentration and } \\
\text { long exposure times } \\
\text { for significant } \\
\text { microbial reductions }\end{array}$ \\
\hline Temperature & Low & Low & Low & Low & Low & Low & Low & Medium to high & Low \\
\hline $\begin{array}{l}\text { Environment } \\
\text { impact }\end{array}$ & $\begin{array}{l}\text { Environmentally } \\
\text { friendly }\end{array}$ & $\begin{array}{l}\text { Environmentally } \\
\text { friendly }\end{array}$ & $\begin{array}{l}\text { Environmentally } \\
\text { friendly }\end{array}$ & $\begin{array}{l}\text { Environmentally } \\
\text { friendly }\end{array}$ & $\begin{array}{l}\text { Environmentally } \\
\text { friendly }\end{array}$ & $\begin{array}{l}\text { Environmentally } \\
\text { friendly }\end{array}$ & $\begin{array}{l}\text { Environmentally } \\
\text { friendly }\end{array}$ & Needs heating & $\begin{array}{l}\text { Environmentally } \\
\text { friendly }\end{array}$ \\
\hline $\begin{array}{l}\text { Energy } \\
\text { efficiency }\end{array}$ & Low energy input & Low energy input & $\begin{array}{l}\text { Low energy } \\
\text { consumption }\end{array}$ & $\begin{array}{l}\text { Low energy } \\
\text { consumption }\end{array}$ & Low energy input & $\begin{array}{l}\text { Low energy } \\
\text { consumption }\end{array}$ & Energy-efficient & $\begin{array}{l}\text { High energy } \\
\text { conversion }\end{array}$ & $\begin{array}{l}\text { Low energy } \\
\text { consumption }\end{array}$ \\
\hline Costs & $\begin{array}{l}\text { Dependent, mainly, } \\
\text { on the gas used } \\
\text { Higher cost for noble } \\
\text { gases. }\end{array}$ & $\begin{array}{l}\text { Competitive } \\
\text { energy costs and } \\
\text { low maintenance } \\
\text { costs }\end{array}$ & $\begin{array}{l}\text { High capital cost } \\
\text { Low operational } \\
\text { and overall costs }\end{array}$ & $\begin{array}{l}\text { Low maintenance, } \\
\text { installation, and } \\
\text { operational costs }\end{array}$ & $\begin{array}{l}\text { High capital cost } \\
\text { Operational costs are } \\
\text { dependent on the } \\
\text { pressure used }\end{array}$ & $\begin{array}{l}\text { Low energy } \\
\text { required and low } \\
\text { costs of operation } \\
\text { High capital cost }\end{array}$ & Low cost & $\begin{array}{l}\text { Needs energy } \\
\text { for heat } \\
\text { production } \\
\text { The material } \\
\text { used in the } \\
\text { electrode design } \\
\text { is important. }\end{array}$ & $\begin{array}{l}\text { It should be } \\
\text { generated on-site. } \\
\text { Costly to maintain } \\
\text { the concentration. }\end{array}$ \\
\hline $\begin{array}{l}\text { Impact on } \\
\text { quality* }\end{array}$ & $\begin{array}{l}\text { Oxidation in high-fat } \\
\text { products }\end{array}$ & $\begin{array}{l}\text { Oxidation of lipids, } \\
\text { denaturation of } \\
\text { proteins, reduction } \\
\text { in the bioactive } \\
\text { compounds }\end{array}$ & $\begin{array}{l}\text { Oxidation of lipids, } \\
\text { off flavors, low } \\
\text { viscosity, color } \\
\text { changes, texture } \\
\text { alterations }\end{array}$ & $\begin{array}{l}\text { Color, flavor, and } \\
\text { aroma changes }\end{array}$ & $\begin{array}{l}\text { Texture changes and } \\
\text { color changes }\end{array}$ & $\begin{array}{l}\text { Color changes, } \\
\text { protein denaturation }\end{array}$ & $\begin{array}{l}\text { Texture changes, } \\
\text { altered sensory } \\
\text { characteristics }\end{array}$ & Color changes & $\begin{array}{l}\text { Physicochemical and } \\
\text { color changes }\end{array}$ \\
\hline
\end{tabular}

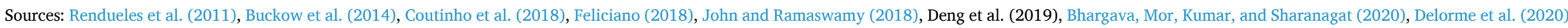
*Dependent on the process parameters. Characteristics in bold are considered positive. 
frequency US (20 kHz or $1 \mathrm{MHz}$; 15 or $30 \mathrm{~min}$ ), whereas the different treatments resulted in reductions lower than 1 log. However, only additive effects were observed when blueberries were treated but without losses in texture or color properties. For the processing, fruits inoculated with pathogenic microorganisms were immersed in a solution with EO and subjected to US (Zhang et al., 2020). In another study, the combined treatment showed no significant effect on total anthocyanin content and total phenolic content. However, it significantly impacted blueberry texture and color, mainly when the low-frequency US was used. Besides, decreases of 2-3 log CFU/g of L. innocua were observed. For the processing, fruits inoculated with pathogenic microorganisms were immersed in EO's solution and subjected to US (Zhang, Tsai, \& Tikekar, 2021). In milk samples with low or high-fat content, the combined treatment of cinnamon EO $(0.312 \mu \mathrm{L} / \mathrm{mL})$ and US $(24 \mathrm{kHz}$ and $400 \mathrm{~W}$ power for $15 \mathrm{~min}$ ) reduced $S$. Typhimurium by 2.7 and $3.8 \mathrm{log}$ cycles and L. monocytogenes by 4.3 and $4.5 \log$ cycles, respectively. The inactivation was higher than that provided by EO individually (2.0-2.2 and 2.5-3.0 $\log$, respectively) or the US separately ( 1.6 and $0.7 \mathrm{log}$, respectively). For the processing, milk was inoculated with the pathogenic microorganisms, added with EO, and subjected to US (Mortazavi \& Aliakbarlu, 2019).

The synergistic effect of US and EOs may be associated with the US's ability to reduce the size of the EO droplets, thereby resulting in improved bioactivity, as smaller particle size increases the amount of contact of EO with the microorganisms (Millan-Sango et al., 2016). Due to the cavitation process, the US may also weaken the microbial cell wall and form pores, thereby improving the antimicrobial activity of EOs (Sánchez-Rubio et al., 2016). Simultaneously, the bioactive compounds of EOs may accumulate in the lipid bilayer of the microbial cell, sensitizing it and making it more vulnerable to the action of the US (Sánchez-Rubio et al., 2016). Finally, the US may disrupt the membrane homeostasis by promoting membrane disintegration, increasing the outer and inner membrane permeability, the entrance of EOs in the cells, and inactivation of microorganisms (Guo et al., 2020, He, Liu, et al., 2021 ,b). Based on the results of these studies, the US may have a synergistic effect with EOs (oregano, thyme, cinnamon, citral, carvacrol, and geraniol) for purposes of inactivation of foodborne pathogens (Salmonella, Listeria, and E. coli) and spoilage microorganisms (S. cerevisiae) in food products (vegetables, juices, fruits, and milk). However, the efficacy of the combined effect of US and EOs requires further evaluation given its impact on the products' sensory and technological characteristics.

\subsection{Essential oils and irradiation}

IR consists of exposing food to ionizing radiation for microbial inactivation purposes (Maherani et al., 2016). IR can be obtained from gamma rays, electron beams, or X-rays; the three sources are considered equally safe and effective according to international food safety standards (Begum et al., 2020; Hossain et al., 2019a). The most common source of IR for food treatment is the radioisotope cobalt-60 (Gamma radiation). IR can break DNA chemical bonds and alter membrane permeability in microbial cells. IR also leads to the intracellular increase of ROS, thereby compromising a range of cellular functions (Begum et al., 2020). In foods, the IR doses allowed for application in reducing pathogens lie between 0.5 and $30 \mathrm{kGy}$. The relevant processing parameters for microbial inactivation are the source of radiation, processing time, and length of penetration (Abdeldaiem, Mohammad, \& Ramadan, 2018).

The application of IR to food products may be effective in extending the shelf life of food products through the inactivation of pathogens and spoilage microorganisms while maintaining nutritional and sensory characteristics (Table 2). However, IR can modify the chemical composition and the nutritional value of foods; furthermore, it can compromise sensory aspects, as irradiated foods have been shown to present off-flavors, low viscosity, changes in color (darkening or discoloration), and altered texture (Feliciano, 2018). Furthermore, IR may increase lipid oxidation due to polyunsaturated fatty acids' reactions with ROS during storage (Abdeldaiem et al., 2018).

IR and EOs combined as a preservation method have been used in unprocessed cereals and flours (Table 1, Figs. 1 and 2). Zallaghi and Ahmadi (2020) investigated the action of Lavandula angustifolia Miller EO $(1.14,1.7,2.5,4.03$, and $6.42 \mathrm{~mL} / \mathrm{L})$ and gamma IR treatment (50, 100 , and $200 \mathrm{~Gy}$ ) on specific properties of the Ephestia kuehniella (Zeller) moth from Mediterranean flour. Results suggested that irradiated and fumigated larvae's consumption and growth rates were lower than those observed in the non-treated samples. Therefore, a combined treatment of EO and IR displayed a greater fumigant activity than the individual treatments. In another study, irradiation and fumigation using a thyme and oregano EO mixture resulted in increased inactivation of Bacillus cereus, Aspergillus niger, and Paenibacillus amylolyticus in rice and its derivatives (Shankar et al., 2020).

Recent interventions in the fish processing sector have gained importance, such as combining a mixture of EOs and citrus extract (1.6\%) with gamma irradiation (1 kGy). The combined treatment increased the fish fillets' shelf-life from 7 days to $>28$ days by reducing microbial growth. This approach, therefore, improved the safety and quality of the product (Shankar, Danneels, \& Lacroix, 2019). Abdeldaiem et al. (2018) reported that coated (rosemary EO, 0.5\%) and irradiated (1 kGy) silver carp fish fillets displayed decreased $S$. aureus, Enterobacteriaceae, and $B$. cereus counts. Improvements in product quality were thus demonstrably obtained.

Both IR and EOs affect cell membrane integrity and composition, thereby inducing cell constituents' release, leading to a decrease of the internal ATP and $\mathrm{pH}$. In combination, they increase microbial inactivation in food matrices by facilitating contact between antimicrobial compounds and cell membranes, thus increasing the degree of damage (Hossain et al., 2019a,b, Begum et al., 2020). Furthermore, IR application may facilitate EO's penetration in foodstuffs, thereby increasing overall antimicrobial effectiveness (Zallaghi \& Ahmadi, 2020). Based on the results of these studies, IR may have a synergistic effect with EO for purposes of inactivation of foodborne pathogens (Salmonella, Listeria, Vibrio, B. cereus, S. aureus) and molds (A. oryzae, Aspergillus, and Fusarium) in food products (flour, fish, maize, and rice). A combined treatment can ensure the maintenance of sensory characteristics of food products that would be affected by IR individually, mainly due to the utilization of lower intensities of IR and lower concentrations of EO in combined treatment. However, further studies are necessary to prove this proposition. Other food matrices, mainly of animal origin, should be likewise evaluated.

\subsection{Essential oils and ultraviolet light}

UV-C is a physical treatment designed to expose food to direct action of short-wave UV-C or UV radiations (200-280 nm). Such irradiation processes usually aim to enhance the product's safety and shelf-life (Tawema, Han, Vu, Salmieri, \& Lacroix, 2016). The antimicrobial effect of UV-C is based on its ability to disrupt the microorganisms' DNA, inducing the cross-linking of pyrimidine nucleotide bases over the same strand of DNA, altering microbial reproduction metabolism, and leading to cell death. Furthermore, UV-C can alter cells' enzyme activity and damage cell membrane integrity (Ferrario, Fenoglio, Chantada, \& Guerrero, 2020). The relevant processing parameters for microbial inactivation are processing time and temperature, UV dose, wavelength, and UV light source (Delorme et al., 2020).

UV-C application may effectively induce spoilage and pathogenic microorganisms, resulting in products with low loss of sensory and nutritional quality (Table 2). This technology offers many advantages such as safety and non-toxicity; maintenance and investment costs are low, and the treatment is environmentally friendly. Furthermore, it is energy efficient, with a total energy consumption much lower than heat pasteurization, HHP, or PEF (Delorme et al., 2020). However, UV-C has 
low penetration capacity in food products, may alter flavor characteristics, does not eliminate spores, and maybe not efficient in the inactivation of certain pathogens (Delorme et al., 2020). To overcome these limitations, UV-based technologies have been applied in combined treatments with several different EOs.

EOs in combination with UV-C have already been used to increase foodstuffs' quality and safety, mainly of plant-based products (Table 1 , Figs. 1 and 2). The treatment of cinnamon bark EO emulsions $(0.02 \%)$ combined with UV-C $\left(1.2 \mathrm{~kJ} / \mathrm{m}^{2}, 2 \mathrm{~min}\right)$ decreased the $S$. Typhimurium, and L. monocytogenes counts in fresh-cut red chard by 1.40 and $1.29 \mathrm{log}$ $\mathrm{CFU} / \mathrm{g}$, respectively. EO utilization individually resulted in decreases of $0.38-0.55 \log \mathrm{CFU} / \mathrm{g}$ for $S$. Typhimurium and 0.27-0.31 log CFU/g for $L$. monocytogenes, while the sole application of UV-C decreased the counts in 0.4 and $0.6 \operatorname{logs} \mathrm{CFU} / \mathrm{g}$, respectively. EO and UV-C, therefore, exerted an additive effect. The sensory evaluation results demonstrated that combined treatment had no impact on product quality (Park, Kang, \& Song, 2018). In another study, emulsions of citral with vanillin $(300-400 \mu \mathrm{g} / \mathrm{mL})$ in combination with UV-C $\left(0-390 \mathrm{~mJ} / \mathrm{cm}^{2}\right)$ caused at least 5 log-reductions of Lactiplantibacillus plantarum (formerly Lactobacillus plantarum), S. cerevisiae, and $E$. coli in juice blends, i.e., tangerine-orange and orange-mango-bananakiwi-strawberry. The combined effect was considered synergistic for $S$. cerevisiae and additive for E. coli (Ferrario et al., 2020).

A combined treatment of clove EO (1.56\%) and UV-C $(0.6-12.0 \mathrm{~kJ} /$ $\mathrm{m}^{2}$ ) on the surface of dehydrated persimmon caused reductions of Rhizopus oryzae and Aspergillus niger by 0.64 and by $0.68 \log \mathrm{CFU} / \mathrm{cm}^{2}$, respectively, and enhanced the products' shelf-life by more than 28 days. Overall acceptability, texture, flavor, and appearance were not affected according to the sensory evaluation data. The results demonstrated that UV-C treatments had a limited impact on the reductions of mold counts when used individually, regardless of the dose; however, they could increase EO's effect in the combined treatment (Vurmaz \& Günduiz, 2020). Moreover, S. Typhimurium biofilms were eliminated (6.8 logs $\left.\mathrm{CFU} / \mathrm{cm}^{2}\right)$ through the combination of clove EO $(1.2 \mathrm{mg} / \mathrm{mL})$ and UV-C $\left(76.41 \mathrm{~mJ} / \mathrm{cm}^{2}\right)$ on stainless steel, demonstrating a synergistic effect. EO reduced only $1.8 \log \mathrm{CFU} / \mathrm{cm}^{2}$ when used individually, while UV-C reduced $2.9 \log \mathrm{CFU} / \mathrm{cm}^{2}$ (Silva-Espinoza et al., 2020).

EO and UV-C's synergistic effect may be associated with a greater degree of damage to microbial cells compared with the utilization of the technologies separately: combined treatment increases cell permeability and causes more leakage of constituents (Park et al., 2018). In biofilms, EOs may cause structural damages and produce a flatter structure, which, in turn, allow for a higher inactivation rate of UV-C due to increased accessibility to the microbial cells (Silva-Espinoza et al., 2020). Based on these studies' results, UV-C may have a synergistic effect in combination with EO (cinnamon, citral with vanillin, and clove) for purposes of inactivation of foodborne pathogens (Salmonella, Listeria), spoilage (Lactiplantibacillus plantarum), and molds (Rhizopus oryzae and Aspergillus niger) in food products (fresh-cut red chard, juice blends, and fruits) and on surfaces. Combined treatment may result in the inactivation of microorganisms resistant to UV-C or spores and reduce the negative impact of this technology on food products' sensory characteristics. However, further studies are necessary to evaluate the effect of the combined treatment in food products that require penetration to access the pathogens, as this is a limitation of UV-C that EO can improve.

\subsection{Essential oils and high hydrostatic processing}

HHP consists of exposing food to high hydrostatic pressure ranging from 100 to $800 \mathrm{MPa}$. Antimicrobial inactivation is associated with HHP action on the microbial cell membrane, protein denaturation, and DNA, RNA, or protein synthesis inhibition. Also, HHP may cause modifications in intracellular organelles, resulting in cell lengthening, pores' formation, and the release of intracellular constituents. The relevant processing parameters for microbial inactivation are pressure, processing time, and temperature (Agregán et al., 2021).

HHP can inactivate foodborne pathogens at room temperature and increase the shelf-life of food products under refrigerated storage while preserving foods' sensory characteristics and nutritional value (Chien, Sheen, Sommers, \& Sheen, 2019) (Table 2). Furthermore, it is regarded as an environmentally friendly technology while requiring a lower energy input than conventional heating. However, HHP can impair texture and color, increase lipid oxidation, and result in injured cells recovering if appropriate post-processing conditions are found (Rendueles et al., 2011). Therefore, combined treatments of HHP with EO may be a suitable alternative to overcome these disadvantages.

The utilization of $1.0 \%$ geraniol, $1.0 \%$ citral, $1.0 \%$ MIX (one-third $\beta$-caryophyllene, one-third geraniol, and one-third citral [weight basis]), and $1.0 \%$ M. officinalis EO and 350 and $400 \mathrm{MPa}$ can decrease E. coli counts by 3-6 $\log \mathrm{CFU} / \mathrm{g}$ in fresh ground beef. The efficiency of inactivation was maintained over storage time $\left(4{ }^{\circ} \mathrm{C}\right.$ for 7 days). The treatments did not result in changes in texture parameters, although a slight color alteration was observed (toward pale white). This study reported that a lower pressure could be used in the combined treatment (Chien et al., 2019). Carvalho et al. (2018) investigated the combined effects of HHP (300, 200, and $150 \mathrm{MPa}, 15 \mathrm{~min}$ ) and suspensions and nanoemulsions of Mentha piperita EO $(0.63,0.31$, and $0.16 \mu \mathrm{L} / \mathrm{mL})$ on E. coli O157:H7 (7 logs $\mathrm{CFU} / \mathrm{mL}$ ) populations in mango and guava juices. The combination of 200 and $300 \mathrm{MPa}$ for $15 \mathrm{~min}$ and nanoemulsions of M. piperita $(0.31$ and $0.63 \mu \mathrm{L} / \mathrm{mL})$ decreased $E$. coli $\mathrm{O} 157: \mathrm{H7}$ counts by 5 $\log$ cycles in both juices.

Donsì et al. (2015) studied green beans covered with a chitosan coating containing a nanoemulsion of mandarin EO (2\%) and submitted to HHP ( $5 \mathrm{~min}, 400 \mathrm{MPa}$ ). The HHP and the coating acted synergistically, exerting a pronounced antimicrobial effect on the L. innocua counts, mainly in the first days of storage, with decreases of $4 \log \mathrm{CFU} / \mathrm{g}$. Nevertheless, antimicrobial activity was reduced during storage because the coating layer disintegrated. Furthermore, the firmness and color of the products were negatively impacted. The results suggest that a synergistic effect can be observed in the combined treatment of HHP and EO.

The synergistic effect of EOs and HHP may be associated with greater damage to the cell membrane structure compared with the utilization of the technologies separately, thus potentially increasing the combined treatment's impact on the cells' physiological functions (Carvalho et al., 2018). Furthermore, it has been postulated that HHP may alter cell membrane structure and increase microorganisms' sensitivity to EOs (Chien et al., 2019). Based on the results of these studies, HHP may have a synergistic effect in conjunction with EO ( $\beta$-caryophyllene, geraniol, citral $M$. officinalis, Mentha piperita, mandarin) for the inactivation of foodborne pathogens (E. coli O157:H7 and L. innocua) in food products (meat, fruit juices, and beans). Combined treatment may result in the inactivation of pathogens that would have been capable of resisting the sole application of HHP. However, further studies are necessary to investigate this combined technology's impact on sensory attributes and its efficacy in other food products.

\subsection{Essential oils and pulsed electric fields or pulsed light}

PEF treatment (pulsed electric fields) consists of the application of $1-100 \mu$ s pulses of $10-50 \mathrm{kV} / \mathrm{cm}$ electric fields to fluid food that is placed between two electrodes in continuous or batch flow systems using low processing temperatures (Sagarzazu, Cebrián, Pagán, Condón, \& Mañas, 2013). The antimicrobial effect of PEF is mainly associated with electroporation and electrical breakdown, which may increase the permeabilization of the cell membrane and form pores, resulting in cell death (Novickij et al., 2020). It has been postulated that PEF may form hydrophilic pores in cell membranes and protein channels (Buckow, Chandry, Ng, McAuley, \& Swanson, 2014). For liquid foods, electric field strengths of $20-250 \mathrm{kV} / \mathrm{cm}$, processing times of $20-1000 \mu \mathrm{s}$, and temperatures of $30-40{ }^{\circ} \mathrm{C}$ resulted in performances with an efficacy 
comparable to conventional pasteurization (Wang et al., 2018). The relevant processing parameters for microbial inactivation are electrical field strength, wave shape, number of pulses, pulse frequency, pulse width, temperature, and processing time (Wang et al., 2018).

PEF treatments present several advantages (Table 2): inactivation of microorganisms at low temperatures, preservation of functional and sensory properties, a low incidence of rotting problems, lower energy consumption compared to conventional heating, and a longer time needed until the equipment requires cleaning (Buckow et al., 2014). However, specific foodborne pathogens, mold ascospores, and bacterial spores may resist PEF treatment, and it is recommended to be used in combination with other methods (Novickij et al., 2020).

Pagán, Berdejo, Espina, García-Gonzalo, and Pagán (2018) examined the antimicrobial activity of suspensions and nanoemulsions of citral $(0.7 \mu \mathrm{L} / \mathrm{mL})$, combined with heat or PEF $(150 \mu \mathrm{s}, 30 \mathrm{kV})$, in apple juices. Decreases of $5 \log$ cycles of $E$. coli O157:H7 were reported when 0.1 $\mu \mathrm{L} / \mathrm{mL}$ of citral and PEF (150 $\mu \mathrm{s}, 30 \mathrm{kV}$ ) were used in combination, whereas the sole utilization of PEF reduced only 1 log CFU. In another study, the synergistic antimicrobial effect of PEF $(150 \mu \mathrm{s}, 30 \mathrm{kV})$ and suspensions and nanoemulsions of Mentha piperita L. EO $(0.16,0.31$, and $0.63 \mu \mathrm{L} / \mathrm{mL}$ ) on the E. coli O157: $\mathrm{H} 7$ (7 logs CFU/mL) counts in mango and guava juices were studied. Decreases of $5 \log \mathrm{CFU} / \mathrm{mL}$ of $E$. coli O157: H7 were noticed after the treatment, while no significant reductions were observed for EO individually, and PEF individually reduced 2.3-4.2 log. This study demonstrated that the achieved antimicrobial synergism was dependent on the form of EO addition (nanoemulsion or suspension), the concentration used, and the food type: the antimicrobial effect was greater with nanoemulsions, in juices with lower pH, and with higher EO concentrations (Carvalho et al., 2018). Clemente, Condón-Abanto, Pedrós-Garrido, Whyteb, and Lyng (2020) noticed decreases of $1.5 \mathrm{log} \mathrm{CFU} / \mathrm{g}$ of Campylobacter jejuni in raw chicken when $62.5 \mu \mathrm{g} / \mathrm{mL}$ of oregano EO and PEF $(1 \mathrm{kV} / \mathrm{cm}, 1 \mathrm{~Hz}, 20 \mu \mathrm{s})$ were applied in combination. The latter study demonstrated that the synergistic effect was dependent on the type of application, as the utilization of both methodologies together did not result in a synergistic effect, while the application of PEF and subsequent immersion in EO did.

The synergistic effect of EOs and PEF may be associated with the ability of PEF to cause sublethal injuries and even non-permanent pores on the cell envelopes, thereby facilitating the antimicrobial activity of EOs (Wang et al., 2018). Combined treatment may result in the inactivation of pathogens that would resist the sole application of PEF. However, further studies are necessary to evaluate this combined technology's influence on the products' sensory properties and its impact on a higher diversity of pathogens and food products.

PL (pulsed light) consists of exposing a sample to a repetitive sequence of $100 \mathrm{~ns}$ to $1 \mathrm{~ms}$ of flashes/high-intensity pulses of 200 nm-1100 nm light, i.e., multiple optical frequencies. They are obtained with a xenon flash lamp; ca. $40 \%$ of the emitted light is in the UV range (Oms-Oliu, Martín-Belloso, \& Soliva-Fortuny, 2010). PL's antimicrobial activity is associated with radiation absorption by the double bonds of nucleic acids and proteins, resulting in changes in the cell's DNA. In the case of the virus, breakdown of the RNA strand, damages to structure and protein, and capsid rupture have been reported. It has been postulated that PL's application may result in photothermal, photochemical, and photophysical effects. The microbial cell wall may thus be destroyed, and the cytoplasm can shrink. The relevant processing parameters for microbial inactivation are pulse fluence, pulse width, frequency, UV content, processing time, and peak power (John \& Ramaswamy, 2018).

PL offers many advantages (Table 2): it is effective in the inactivation of different types of microorganisms (bacteria, molds, virus, and yeast), it is competitive or has a lower cost compared to other technologies used for food disinfection, it forms no residues, it is environmentally friendly and safe, and it is capable of preserving the nutritional and sensory properties of food products. However, its penetration ability is low; high inactivation rates are only achieved on the product's surface or in non- opaque products (John \& Ramaswamy, 2018). Combined treatments with EO may therefore improve its capacity for inactivation.

The effect of combining a specific chitosan coating, including nanoemulsions of carvacrol with PL $\left(4,8\right.$, and $\left.12 \mathrm{~J} / \mathrm{cm}^{2}\right)$ in decontamination of slices of fresh-cut cucumber, was reported. In that study, the combination of PL and carvacrol had a more intense effect, resulting in a strong synergism with more than 5 logs $\mathrm{CFU} / \mathrm{g}$ decrease in the population of $E$. coli ATCC 26. In contrast, the utilization of coating and coating + carvacrol provided no microbial reduction or reduced only 1 log cycle, respectively. This study reported that the increase in pulse fluence resulted in higher inactivation rates (Taştan, Pataro, Donsì, Ferrari, \& Baysal, 2017).

EOs and PL's synergistic effect may be attributed to the ability of EOs to increase membrane permeability, facilitating the access of PL to the cell's genetic material, cytoplasm, and proteins. Based on the study results mentioned above, PL may have a synergistic effect in combination with EO (carvacrol) for the inactivation of foodborne pathogens (E. coli ATCC 26) in food packages for cucumber. However, further studies are necessary to evaluate this combined technology's influence on the products' sensory properties as well as its impact on a wide diversity of pathogens and food products (mainly those that require penetration to access the pathogens, as this is a limitation of PL that EO can improve).

\subsection{Essential oils and ohmic heating}

$\mathrm{OH}$ (ohmic heating, also referred to as Joule heating) is a novel thermal process that consists of passing an alternating electric current through food samples to facilitate rapid and uniform heating (Al-Hilphy, Al-Musafer, \& Gavahian, 2020). Electrical energy is converted into thermal energy by the food's electrical resistance, resulting in instantaneous and volumetric heating (Cappato et al., 2017). The treatment's antimicrobial activity is associated with thermal and non-thermal effects (electroporation), which damage the membranes and wall of the microbial cells, modify their permeability, and promote cytoplasm aggregation/pore formation. Electroporation is provoked by the electrical field, which increases membrane conductance and results in leakage of intracellular material (Makroo, Rastogi, \& Srivastava, 2020). The relevant processing parameters for microbial inactivation are electrical field strength, processing time, temperature, and electrical current frequency. Commonly applied electrical conductivities are in the range of 0.01-10 $\mathrm{S} / \mathrm{m}$ at ambient temperature $\left(25^{\circ} \mathrm{C}\right)$ and low frequencies $(50-60 \mathrm{~Hz})$, which allow for the observation of non-thermal effects (Cappato et al., 2017).

OH has many advantages for microbial inactivation (Table 2), such as uniform and fast heating, processing times lower than conventional heating, ease of control, and greater retention of nutrients and sensory characteristics (Makroo et al., 2020). Furthermore, it offers high energy efficiency, as most of the electrical energy (90\%) can be converted into heating, whereas in other emerging technologies, this conversion is low ( $50 \%$ for microwaves) (Cappato et al., 2017). However, if $\mathrm{OH}$ is applied in severe conditions, the quality or nutritional aspects of food products may be compromised (Kim \& Kang, 2017a). Also, OH efficacy may be affected by the electrical conductivity of the components present in the food matrix (mainly fat), which exert a protective effect on microorganisms (Cappato et al., 2017). Another point that may limit OH's use as a single agent is its effect on color parameters. Therefore, it is recommended to apply the hurdle concept by combining $\mathrm{OH}$ with other technologies that pay better heed to safety and quality concerns, such as EO.

Kim and Kang (2017a) reported the combination of $\mathrm{OH}$ (60 s and 38 s; $1 \mathrm{mHz}-10 \mathrm{MHz}$ ) with several EOs constituents (eugenol, carvone, citral, and thymol) for the inactivation of foodborne pathogens, including E. coli O157:H7, S. Typhimurium, and L. monocytogenes, in salsa. Firstly, the combined treatment of citral with $\mathrm{OH}$ presented the most pronounced antimicrobial effect on pathogen counts in buffered peptone water (reductions of 4.3-5.7 $\log \mathrm{CFU} / \mathrm{mL}$ ). However, when the 
application was made in salsa, the inactivation was most effective in combining $\mathrm{OH}$ and thymol, proceeded by citral, eugenol, and carvone. The combination of $\mathrm{OH}$ and thymol also improved the color of the product ( $\mathrm{b} *$ value). This study demonstrated that processing time, the type of EO, and the type of food matrix all play a vital role in the combined treatment's effectiveness, as synergistic effects with $\mathrm{OH}$ were observed only with citral and thymol. In another study combining carvacrol with $\mathrm{OH}$, it was observed that only $50 \mathrm{~s}$ and $60 \mathrm{~Hz}$ were required to inactivate all pathogens $(>5 \log$ reduction, E. coli O157:H7, $S$. Typhimurium, and $L$. monocytogenes) while $75 \mathrm{~s}$ were needed when $\mathrm{OH}$ was applied individually. Furthermore, temperature increase was reduced by $20{ }^{\circ} \mathrm{C}$ for the combined treatment, resulting in improved product quality characteristics, particularly color. Finally, the combined treatment was the only one able to inactivate MS-2 bacteriophage (reductions of $6.2 \mathrm{log}$ ) in $100 \mathrm{~s}$, resulting in virucidal activity (Kim \& Kang, 2017b).

EOs and OH's synergistic effect may be associated with the ability of EOs to cause severe depolarization in cell membranes and enhance membrane destruction when combined with $\mathrm{OH}$, thereby causing higher inactivation levels (Kim \& Kang, 2017a). However, when applying combinations of $\mathrm{OH}$ and EOs, a longer treatment time is needed for synergistic virucidal effects in comparison to bactericidal ones (Kim \& Kang, 2017a). Based on the results of these studies, OH may have a synergistic effect in combination with EO (citral and thymol) for the inactivation of foodborne pathogens (E. coli O157:H7, S. Typhimurium, L. monocytogenes, and virus) in food products (salsa). Combined treatment may result in the inactivation of viruses that are resistant to $\mathrm{OH}$ and reduce the impact of $\mathrm{OH}$ on the sensory characteristics of food products, mainly color. However, further investigations are necessary to evaluate the combined treatment effect on other food products since only salsa was evaluated.

\subsection{Essential oils and ozone}

Ozone is a gas found naturally in the atmosphere (Pandiselvam, Sunoj, Manikantan, Kothakota, \& Hebbar, 2016). This gas is usually generated by passing air or oxygen through an electrical high-voltage discharge for food processing. The antimicrobial effect of ozone is associated with oxidation of cell constituents (proteins, enzymes, peptidoglycans, lipids, and nucleic acids), disintegration or disruption of the cell membrane, and leakage intracellular components. Furthermore, ozone may damage RNA and DNA, mainly due to the action of free radicals. The two most relevant processing parameters for microbial inactivation are 1) concentration and form of ozone and 2) processing time (Deng et al., 2020; Pandiselvam et al., 2020).

The application of ozone offers several advantages (Table 2): increased reactivity, oxidation power, the capacity of penetration, no formation of residues, low energy consumption, and antimicrobial activity against a series of microorganisms (fungi, bacteria, virus, and spores) (Pandiselvam et al., 2018). However, ozone presents important limitations, such as the need for high concentrations of ozone and long processing times to reduce significant counts of microorganisms, changes in the physicochemical properties and color parameters of food products, decreases in the concentration of bioactive compounds, and alteration in the sensory profile (Deng et al., 2020). The association of ozone with EO may be an interesting approach to help overcome both treatments' limitations.

The utilization of a mixture of EOs and citrus extract (1.6\%) with ozone (10 ppm, $15 \mathrm{~min}$ ) increased the shelf-life of fish fillets from 7 days to $>21$ days by reducing microbial growth. This approach, therefore, improved the safety and quality of the product (Shankar et al., 2019). In another study, ozone was combined with EO (carvacrol, oregano oil, olive extract, and Quillaja saponin) as a substitute for chlorine in the washing of lettuce. For processing, lettuce was inoculated with $S$. enterica, washed with a solution of water and EO, and subjected to ozonation. The combined treatments of ozone and $0.5 \%$ oregano oil for
$60 \mathrm{~min}$ and ozone and carvacrol $(0.1,0.3$, or $0.5 \%)$ resulted in reductions of $S$. enterica counts below the limit of detection $(10 \mathrm{CFU} / \mathrm{g})$ from an initial concentration of 6 logs $\mathrm{CFU} / \mathrm{g}$. For the other combinations, reductions of 2.23-3.64 log CFU/g (olive extract + ozone) and $1.24 \log \mathrm{CFU} / \mathrm{g}$ (Quillaja saponin + ozone) were observed. The combined treatments did not alter the visual appearance of the products. This study demonstrated that EO's type and concentration and the contact time with ozone are important parameters to be considered (Kumar \& Ravishankar, 2019).

EOs and ozone's synergistic effect may be associated with the ability of EOs to form pores in the cell membrane and facilitate the activity of ozone in the oxidation of cell constituents and damage to DNA. Based on the results of these studies, ozone may have a synergistic effect with EO (citrus extract, carvacrol, and oregano oil) for purposes of inactivation of foodborne pathogens ( $S$. enterica) in food products (fish fillets and lettuce). Combined treatment may allow for lower ozone concentrations and lower intensities of $\mathrm{EO}$ and/or reduce processing time. Furthermore, it may help maintain sensory characteristics. However, further studies are necessary to evaluate the combined treatment's effect on other food products. The synergism between EO and ozone also needs to be better evaluated.

\section{Effect of emerging technologies on essential oils stability}

EOs stability depends on many intrinsic and extrinsic factors, such as chemical structure and impurities in their composition and environmental conditions. The presence of oxygen and its reactive substances, such as in CP, may increase the EO's oxidation, dependent on the temperature and pressure used (Khayyat \& Roselin, 2018). The utilization of light or radiation, such as in PL and UV, may change the composition and structure of EOs, and degradation of monoterpenes has been commonly reported (Khayyat \& Roselin, 2018). UV may also accelerate autoxidation processes by promoting hydrogen's abstraction and the formation of alkyl radicals (Turek \& Stintzing, 2013). Oxidative reactions may be promoted by UV, IR, and HPP (Hashemi, Khaneghah, Tavakolpour, Asnaashari, \& Mahdavian mehr, 2015; Oliveira, Ramos, Ramos, Piccoli, \& Cristianini, 2015). IR may promote isomerization, hydroxylation, and oxidation of EOs (mainly terpenes and derivatives), resulting in new compounds, which may have altered antimicrobial activities (Araújo et al., 2017). Ozone application may promote hydrolysis, reduction, and oxidation of EOs compounds, mainly terpenes (Alves Filho et al., 2019), while PEF may alter the composition and concentration of the EOs compounds (Sadowska, Matwijczuk, Niemczynowicz, Dróżdż, \& Żabiński, 2019). Finally, the higher temperatures in $\mathrm{OH}$ may promote epoxidation, cleavage of double bonds, allylic oxidation, and dehydrogenation of EOs compounds (Khayyat \& Roselin, 2018).

The impact of ETs on the EOs stability is dependent on the process parameters and EO type. No effect of ETs on the qualitative or quantitative composition of EOs has been reported when applying doses used for decontamination, such as after $\gamma$ - and e-beam radiation ( $25 \mathrm{kGy}$ ) on Eucaliptus globulus, Thymus vulgaris, and Lavandula angustifolia EOs (Haddad, Herent, Tilquin, \& Quetin-Leclerq, 2007), and CP (15 min) on clove oil (Yoo et al., 2021). It is important to mention that most of the studies evaluated the synergistic effects of the combined treatments by determining the reductions in the number of pathogenic or spoilage microorganisms and possible impacts on food products' quality parameters. They compared those effects when technologies were used alone or combined and the possible reduction of EO concentration or the intensity of ET process parameters in the combined treatment. Therefore, EO stability is not commonly studied. They considered that if a combined treatment shows a synergistic effect (or even an additive) right after the treatment has finished, the EO was active during the combined treatment. Therefore, it was not degraded by the ET. 


\section{Remarks on the industrial application of ETs in combination with EOs}

The utilization of ETs combined with EOs as alternatives for conventional heating requires at least a 5-log reduction of the target microorganism (Chien et al., 2019); indeed, a reduction of that order was achieved in most of the combined treatments evaluated (Matan et al., 2014, Cui, Ma, et al., 2016, c, Yoo et al., 2021, Millan-Sango et al., 2015, Begum et al., 2020, Ferrario et al., 2020). However, some of the evaluated approaches did not reach the recommended reductions, which can be associated which some factors, such as pathogen inoculation lower than $5 \log$ CFU/g (Cui et al., 2016a; Lin et al., 2019; Hossain et al., 2019a), and evaluation of antimicrobial activity in raw materials (uncontaminated, low microbial counts) (Shankar et al., 2019). In the other cases (Donsì et al., 2015, Park, Kong \& Song, 2018; Mortazavi \& Aliakbarlu, 2019; Clemente et al., 2020; Zhang et al., 2021), further studies should consider how the ET processing parameters and the concentration and type of EO can be optimized to enhance the inactivation rate.

Economic aspects also need to be considered when considering the industrial application of ET associated with EO. The cost of ET utilization is associated with investments in equipment, energy consumption, and overall production costs (Coutinho et al., 2018). On the other hand, EO's costs are related to the cost of raw material and processing (Deng et al., 2020). ETs may have higher costs than conventional heating, and the association between ET and EO may decrease them, as lower concentrations of EO and less intense process parameters of ET may be required to achieve synergistic effects. Furthermore, the improved sensory and nutritional properties of foodstuffs resulting from combined treatments may lead to a higher-quality product, which the food industry can then commercialize at a premium price.

The adoption of ETs by the food industry is dependent on many factors, such as industry characteristics (technological capability, market share, size, absorptive capacity), characteristics of the technology (costs, profitability, advantages, complexity, compatibility with preexistent equipment), and consumer characteristics (perceived risk, attitudes, degree of innovation). ETs may present a series of new challenges, such as determination of processing parameters for each type of food product, decrease in cost, increase in equipment capacity, increased consumer interest, and, in some cases, a series of regulatory issues needing to be resolved (Priyadarshini, Rajauria, O'Donnel, \& Tiwari, 2019).

\section{6. Conclusion and future trends}

This review analyzed the use of combined treatments of EOs with ETs for purposes of food preservation. Combined processes presented synergistic effects on the inactivation of microorganisms and showed a lower impact on the products' sensory attributes and physicochemical properties compared to the use of the technologies separately. Besides, they improved food safety and increased shelf-life. The described synergisms allowed for a minimization of EO doses, which is essential to reduce their sensorial impact. From the same point of view, the intensity of processing parameters (e.g., process duration) of ETs can also be reduced. This is relevant when the technology cannot be applied at extremely high intensity to high flow rates. Besides, the antimicrobial effect of combining EOs and ETs can be associated with the activity of EO in decreasing microorganism's resistance to the subsequent treatment. Such information is essential in order to understand microbial mechanisms of action, discover new synergisms, and improve the actual ones while focusing on areas for further research. Moreover, combined treatments featuring micro- or nano-encapsulated EOs and ETs have shown significant synergism effects that call for further investigation since these are promising strategies that can eventually replace conventional treatments currently used in the food industry. Overall, biofilms in the food processing environments represent a significant problem for the food industry, and combined EOs and ETs might represent a new trend in the endeavor to eliminate them.

\section{CRediT authorship contribution statement}

Geany Targino de Souza Pedrosa: Investigation, Formal analysis, Writing - original draft, Writing - review \& editing, Visualization. Tatiana Colombo Pimentel: Investigation, Formal analysis, Writing original draft, Writing - review \& editing, Visualization. Mohsen Gavahian: Conceptualization, Writing - review \& editing, Visualization. Lorena Lucena de Medeiros: Investigation, Formal analysis, Writing original draft, Writing - review \& editing, Visualization. Rafael Pagán: Conceptualization, Writing - review \& editing, Visualization, Resources, Supervision. Marciane Magnani: Conceptualization, Investigation, Formal analysis, Writing - original draft, Writing - review \& editing, Visualization, Resources, Supervision, Project administration.

\section{Declaration of competing interest}

The authors declare no conflict of interest.

\section{Acknowledgements}

The authors would like to thank "Coordenação de Aperfeiçoamento de Pessoal de Nível Superior” (CAPES-Brazil; 001; PrInt 88881.311776/ 2018-01), Conselho Nacional de Desenvolvimento Científico e Tecnológico" (CNPq-Brazil; 405644/2018-3 and 303437/2017-0) and the Spanish Ministry of Economy, Industry and Competitiveness (Project AGL2015-69565-P) for financial support.

\section{References}

Abdeldaiem, M. H., Mohammad, H. G., \& Ramadan, M. F. (2018). Improving the quality of silver carp fish fillets by Gamma Irradiation and coatings containing Rosemary oil. Journal of Aquatic Food Product Technology, 27, 568-579. https://doi.org/10.1080/ 10498850.2018.1461157

Agregán, R., Munekata, P. E., Zhang, W., Zhang, J., Perez-Santaescolástica, C., \& Lorenzo, J. M. (2021). High-pressure processing in inactivation of Salmonella spp. in food products. Trends in Food Science \& Technology, 107, 31-37. https://doi.org/ 10.1016/j.tifs.2020.11.025

Al-Hilphy, A. R., Al-Musafer, A. M., \& Gavahian, M. (2020). Pilot-scale ohmic heatingassisted extraction of wheat bran bioactive compounds: Effects of the extract on corn oil stability. Food Research International, 137, Article 109649. https://doi.org/ 10.1016/j.foodres.2020.109649

Alves Filho, E. G., Rodrigues, T. H. S., Fernandes, F. A. N., de Brito, E. S., Cullen, P. J., Frias, J. M., ... Rodrigues, S. (2019). An untargeted chemometric evaluation of plasma and ozone processing effect on volatile compounds in orange juice. Innovative Food Science \& Emerging Technologies, 53, 63-69. https://doi.org/10.1016/j. ifset.2017.10.001

Araújo, C. R. R., Corrêa, G. M., Abreu, V. G. C., Silva, T. M., Osorio, A. M. B., Oliveira, P. M., et al. (2017). New insights on gamma rays. Effects of gamma radiation on essential oils: A review. https://doi.org/10.5772/intechopen.68764.

Barbosa, I. M., da Costa Medeiros, J. A., de Oliveira, K.Á. R., Gomes-Neto, N. J., Tavares, J. F., Magnani, M., et al. (2016). Efficacy of the combined application of oregano and rosemary essential oils for the control of Escherichia coli, Listeria monocytogenes and Salmonella Enteritidis in leafy vegetables. Food Control, 59, 468-477. https://doi.org/10.1016/j.foodcont.2015.06.017

Begum, T., Follett, P. A., Hossain, F., Christopher, L., Salmieri, S., \& Lacroix, M. (2020). Microbicidal effectiveness of irradiation from Gamma and X-ray sources at different dose rates against the foodborne illness pathogens Escherichia coli, Salmonella Typhimurium and Listeria monocytogenes in rice. LWT-Food Science and Technology, 132, Article 109841. https://doi.org/10.1016/j.lwt.2020.109841

Berdejo, D., Pagán, E., García-Gonzalo, D., \& Pagán, R. (2019). Exploiting the synergism among physical and chemical processes for improving food safety. Current Opinion in Food Science, 30, 14-20. https://doi.org/10.1016/j.cofs.2018.08.004

Bhargava, N., Mor, R. S., Kumar, K., \& Sharanagat, V. S. (2020). Advances in application of ultrasound in food processing: A review. Ultrasonics Sonochemistry. , Article 105293. https://doi.org/10.1016/j.ultsonch.2020.105293

Boskovic, M., Djordjevic, J., Ivanovic, J., Janjic, J., Zdravkovic, N., Glisic, M., \& Baltic, M. (2017). Inhibition of Salmonella by thyme essential oil and its effect on microbiological and sensory properties of minced pork meat packaged under vacuum and modified atmosphere. International Journal of Food Microbiology, 258, 58-67. https://doi.org/10.1016/j.ijfoodmicro.2017.07.011

Braga, S. P., Lundgren, G. A., Macedo, S. A., Tavares, J. F., dos Santos Vieira, W. A., Câmara, M. P. S., et al. (2019). Application of coatings formed by chitosan and Mentha essential oils to control anthracnose caused by Colletotrichum gloesporioides 
and C. brevisporum in papaya (Carica papaya L.) fruit. International Journal of Biological Macromolecules, 139, 631-639. https://doi.org/10.1016/j. ijbiomac.2019.08.010

Buckow, R., Chandry, P. S., Ng, S. Y., McAuley, C. M., \& Swanson, B. G. (2014). Opportunities and challenges in pulsed electric field processing of dairy products. International Dairy Journal, 34, 199-212. https://doi.org/10.1016/j. idairyj.2013.09.002

Cappato, L. P., Ferreira, M. V., Guimaraes, J. T., Portela, J. B., Costa, A. L., Freitas, M. Q. Cruz, A. G. (2017). Ohmic heating in dairy processing: Relevant aspects for safety and quality. Trends in Food Science \& Technology, 62, 104-112. https://doi.org/ 10.1016/j.tifs.2017.01.010

Carvalho, R. J., de Souza, G. T., Pagán, E., García-Gonzalo, D., Magnani, M., \& Pagán, R. (2018). Nanoemulsions of Mentha piperita L. Essential oil in combination with mild heat, pulsed electric fields (PEF) and high hydrostatic pressure (HHP) as na alternative to inactivate Escherichia coli O157: $\mathrm{H} 7$ in fruit juices. Innovative Food Science \& Emerging Technologies, 48, 219-227. https://doi.org/10.1016/j. ifset.2018.07.004

Chien, S. Y., Sheen, S., Sommers, C., \& Sheen, L. Y. (2019). Combination effect of highpressure processing and essential oil (Melissa officinalis extracts) or their constituents for the inactivation of Escherichia coli in ground beef. Food and Bioprocess Technology, 12, 359-370. https://doi.org/10.1007/s11947-018-2211-5

Clemente, I., Condón-Abanto, S., Pedrós-Garrido, S., Whyteb, P., \& Lyng, J. G. (2020). Efficacy of pulsed electric fields and antimicrobial compounds used alone and in combination for the inactivation of Campylobacter jejuni in liquids and raw chicken. Food Control, 107, Article 106491. https://doi.org/10.1016/j.foodcont.2019.01.017

Coutinho, N. M., Silveira, M. R., Rocha, R. S., Moraes, J., Ferreira, M. V. S., Pimentel, T. C., ... Cruz, A. G. (2018). Cold plasma processing of milk and dairy products. Trends in Food Science \& Technology, 74, 56-68. https://doi.org/10.1016/j tifs. 2018.02.008

Cui, H., Li, W., Li, C., \& Lin, L. (2016). Synergistic effect between Helichrysum italicum essential oil and cold nitrogen plasma against Staphylococcus aureus biofilms on different food-contact surfaces. International Journal of Food Science and Technology, 51(11), 2493-2501.

Cui, H., Ma, C., Li, C., \& Lin, L. (2016). Enhancing the antibacterial activity of thyme oil against Salmonella on eggshell by plasma-assisted process. Food Control, 70, 183-190. https://doi.org/10.1016/j.foodcont.2016.05.056

Cui, H., Ma, C., \& Lin, L. (2016). Synergetic antibacterial efficacy of cold nitrogen plasma and clove oil against Escherichia coli 0157:H7 biofilms on lettuce. Food Control, 66, 8-16. https://doi.org/10.1016/j.foodcont.2016.01.035

Cui, H., Wu, J., Li, C., \& Lin, L. (2016). Promoting anti-listeria activity of lemongrass oil on pork loin by cold nitrogen plasma assist. Journal of Food Safety, 1-10. https://doi. org/10.1111/jfs.12316

Delorme, M. M., Guimarães, J. T., Coutinho, N. M., Balthazar, C. F., Rocha, R. S., Silva, R., \& Cruz, A. G. (2020). Ultraviolet radiation: An interesting technology to preserve quality and safety of milk and dairy foods. Trends in food science \& technology. https://doi.org/10.1016/j.tifs.2020.06.001

Deng, L. Z., Mujumdar, A. S., Pan, Z., Vidyarthi, S. K., Xu, J., Zielinska, M., et al. (2020) Emerging chemical and physical disinfection technologies of fruits and vegetables: A comprehensive review. Critical Reviews in Food Science and Nutrition, 60, 2481-2508. https://doi.org/10.1080/10408398.2019.1649633

Donsì, F., Marchese, E., Maresca, P., Pataro, G., Vu, K. D., Salmieri, S., et al. (2015). Green beans preservation by combination of a modified chitosan based-coating containing nanoemulsion of Mandarin essential oil with high pressure or pulsed light processing. Postharvest Biology and Technology, 106, 21-32. https://doi.org/10.1016/ j.postharvbio.2015.02.006

Espina, L., García-Gonzalo, D., \& Pagán, R. (2014). Synergistic effect of orange essential oil or (+)-limonene with heat treatments to inactivate Escherichia coli 0157:H7 in orange juice at lower intensities while maintaining hedonic acceptability. Food and Bioprocess Technology, 7, 471-481. https://doi.org/10.1007/s11947-013-1076-X

FDA. Food and Drug Administration. (2016). Substances generally recognized as safe. Electronic code of federal regulations 21 cfr 182. U.S. Government Publishing Office. https://www.gpo.gov/fdsys/pkg/CFR-2016-title21-vol3/pdf/CFR-2016-title21-vol3 -sec182-1.pdf Accessed: January, 9, 2021.

Feliciano, C. P. (2018). High-dose irradiated food: Current progress, applications, and prospects. Radiation Physics and Chemistry, 144, 34-36. https://doi.org/10.1016/j. radphyschem.2017.11.010

Ferrario, M., Fenoglio, D., Chantada, A., \& Guerrero, S. (2020). Hurdle processing of turbid fruit juices involving encapsulated citral and vanillin addition and UV-C treatment. International Journal of Food Microbiology, 332, Article 108811. https:// doi.org/10.1016/j.ijfoodmicro.2020.108811

Gavahian, M., Chu, Y. H., Khaneghah, A. M., Barba, F. J., \& Misra, N. N. (2018). A critical analysis of the cold plasma induced lipid oxidation in foods. Trends in Food Science \& Technology, 77, 32-41. https://doi.org/10.1016/j.tifs.2018.04.009

Gavahian, M., \& Cullen, P. J. (2020). Cold plasma as an emerging technique for mycotoxin-free food: Efficacy, mechanisms, and trends. Food Reviews International, 36(2), 193-214. https://doi.org/10.1080/87559129.2019.1630638

Gavahian, M., Peng, H. J., \& Chu, Y. H. (2019). Efficacy of cold plasma in producing Salmonella-free duck eggs: Effects on physical characteristics, lipid oxidation, and fatty acid profile. Journal of Food Science \& Technology, 56(12), 5271-5281. https:// doi.org/10.1007/s13197-019-03996-Z

Guimarães, J. T., Balthazar, C. F., Scudino, H., Pimentel, T. C., Esmerino, E. A., Ashokkumar, M., \& Cruz, A. G. (2019). High-intensity ultrasound: A novel technology for the development of probiotic and prebiotic dairy products. Ultrasonics Sonochemistry, 57, 12-21. https://doi.org/10.1016/j.ultsonch.2019.05.004

Guo, M., Zhang, L., He, Q., Arabi, S. A., Zhao, H., Chen, W., et al. (2020). Synergistic antibacterial effects of ultrasound and thyme essential oils nanoemulsion against
Escherichia coli O157:H7. Ultrasonics Sonochemistry, 66, Article 104988. https://doi. org/10.1016/j.ultsonch.2020.104988

Haddad, M., Herent, M., Tilquin, B., \& Quetin-Leclercq, J. (2007). Effect of Gamma and e-Beam radiation on the essential oils of Thymus vulgaris thymoliferum, Eucalyptus radiata, and Lavandula angustifólia. Journal of Agricultural and Food Chemistry, 6082-6086. https://doi.org/10.1021/jf063540+

Hashemi, S. M. B., Khaneghah, A. M., Tavakolpour, Y., Asnaashari, M., \& Mahdavian mehr, H. (2015). Effects of ultrasound treatment, UV irradiation and avishan-edenaei essential oil on oxidative stability of sunflower oil. Journal of Essential Oil Bearing Plants, 18, 1083-1092. https://doi.org/10.1080/0972060X.2015.1039218

He, Q., Guo, M., Jin, T. Z., Arabi, S. A., \& Liu, D. (2021b). Ultrasound improves the decontamination effect of thyme essential oil nanoemulsions against Escherichia coli O157: H7 on cherry tomatoes. International Journal of Food Microbiology, 337, 108936. https://doi.org/10.1016/j.ijfoodmicro.2020.108936

He, Q., Liu, D., Ashokkumar, M., Ye, X., Jin, T. Z., \& Guo, M. (2021). Antibacterial mechanism of ultrasound against Escherichia coli: Alterations in membrane microstructures and properties. Ultrasonics Sonochemistry, 73, Article 105509. https://doi.org/10.1016/j.ultsonch.2021.105509

Hossain, F., Follett, P., Salmieri, S., Vu, K. D., Fraschini, C., \& Lacroix, M. (2019a). Antifungal activities of combined treatments of irradiation and essential oils (Eos) encapsulated chitosan nanocomposite films in in vitro and in situ conditions. International Journal of Food Microbiology, 295, 33-40. https://doi.org/10.1016/j. ijfoodmicro.2019.02.009

Hossain, F., Follett, P., Salmieri, S., Vu, S. D., Harich, M., \& Lacroix, M. (2019c). Synergistic effects of Nanocomposite films containing essential oil nanoemulsions in combination with ionizing radiation for control of rice weevil Sitophilus oryzae in stored grains. Journal of Food Science, 84, 1439-1446. https://doi.org/10.1111/ 1750-3841.14603

Hossain, F., Follett, P., Vu, K. D., Salmieri, S., Fraschini, C., Jamshidian, M., et al. (2019b). Antifungal activity of combined treatments of active methyl-cellulosebased films containing encapsulated nanoemulsion of essential oils and $\gamma$-irradiation: In vitro and in situ evaluations. Cellulose, 26, 1335-1354. https://doi.org/10.1007/ s10570-018-2135-2, 456789.

John, D., \& Ramaswamy, H. S. (2018). Pulsed light technology to enhance food safety and quality: A mini-review. Current Opinion in Food Science, 23, 70-79. https://doi. org/10.1016/j.cofs.2018.06.004

Kalagatur, N. K., Mudili, V., Kamasani, J. R., \& Siddaiah, C. (2018). Discrete and combined effects of Ylang-Ylang (Cananga odorata) essential oil and gamma irradiation on growth and mycotoxins production by Fusarium graminearum in maize. Food Control, 94, 276-283. https://doi.org/10.1016/j.foodcont.2018.07.030

Khayyat, S. A., \& Roselin, L. S. (2018). Recent progress in photochemical reaction on main components of some essential oils. Journal of Saudi Chemical Society, 22, 855-875. https://doi.org/10.1016/j.jscs.2018.01.008

Kim, S. S., \& Kang, D. H. (2017a). Combination treatment of ohmic heating with various essential oil components for inactivation of foodborne pathogens in buffered peptone water and salsa. Food Control, 80, 29-36. https://doi.org/10.1016/j. foodcont.2017.04.001

Kim, S. S., \& Kang, D. H. (2017b). Synergistic effect of carvacrol and ohmic heating for inactivation of E. coli O157:H7, S. Typhimurium, L. monocytogenes, and MS-2 bacteriophage in salsa. Food Control, 73, 300-305. https://doi.org/10.1016/j. foodcont.2016.08.022

Kumar, G. D., \& Ravishankar, S. (2019). Ozonized water with plant antimicrobials: An effective method to inactivate Salmonella enterica on iceberg lettuce in the produce wash water. Environmental Research, 171, 213-217. https://doi.org/10.1016/j. envres.2018.11.023

Lin, L., Liao, X., \& Cui, H. (2019). Cold plasma treated thyme essential oil/silk fibroin nanofibers against Salmonella Typhimurium in poultry meat. Food Packaging and Shelflife, 21, Article 100337.

Maherani, B., Hossain, F., Criado, P., Ben-Fadhel, Y., Salmieri, S., \& Lacroix, M. (2016). World market development and consumer acceptance of irradiation technology. Foods, 5, 79.

Makroo, H. A., Rastogi, N. K., \& Srivastava, B. (2020). Ohmic heating assisted inactivation of enzymes and microorganisms in foods: A review. Trends in Food Science \& Technology, 97, 451-465. https://doi.org/10.1016/j.tifs.2020.01.015

Matan, N., Nisoa, M., \& Matan, N. (2014). Antibacterial activity of essential oils and their main components enhanced by atmospheric RF plasma. Food Control, 39, 97-99. https://doi.org/10.1016/j.foodcont.2013.10.030

Millan-Sango, D., Garroni, E., Farrugia, C., Van Impe, J. F. M., \& Valdramidis, V. P. (2016). Determination of the efficacy of ultrasound combined with essential oils on the decontamination of Salmonella inoculated lettuce leaves. LebensmittelWissenschaft und -Technologie- Food Science and Technology, 73, 80-87. https://doi org/10.1016/j.lwt.2016.05.039

Millan-Sango, D., McElhatton, A., \& Valdramidis, V. P. (2015). Determination of the efficacy of ultrasound in combination with essential oil of oregano for the decontamination of Escherichia coli on inoculated lettuce leaves. Food Research International, 67, 145-154.

Misra, N. N., Koubaa, M., Roohinejad, S., Juliano, P., Alpas, H., Inácio, R. S., et al. (2017). Landmarks in the historical development of twenty first century food processing technologies. Food Research International, 97, 318-339. https://doi.org/ 10.1016/j.foodres.2017.05.001

Mortazavi, N., \& Aliakbarlu, J. (2019). Antibacterial effects of ultrasound, cinnamon essential oil, and their combination against Listeria monocytogenes and Salmonella Typhimurium in milk. Journal of Food Science, 1-7. https://doi.org/10.1111/17503841.14914

Novickij, V., Stanevičienè, R., Staigvila, G., Gruškienè, R., Sereikaite, J., Girkontaitè, I., \& Servienè, E. (2020). Effects of pulsed electric fields and mild thermal treatment on 
antimicrobial efficacy of nisin-loaded pectin nanoparticles for food preservation. Lebensmittel-Wissenschaft \& Technologie, 120, 108915. https://doi.org/10.1016/j. lwt.2019.108915

Oliveira, T. L. C., Ramos, A. L., Ramos, E. M., Piccoli, R. H., \& Cristianini, M. (2015). Natural antimicrobials as additional hurdles to preservation of foods by high pressure processing. Trends in Food Science \& Technology, 45(1), 60-85. https://doi. org/10.1016/j.tifs.2015.05.007

Oms-Oliu, G., Martín-Belloso, O., \& Soliva-Fortuny, R. (2010). Pulsed light treatments for food preservation. A review. Food and Bioprocess Technology, 3, 13-23.

Pagán, E., Berdejo, D., Espina, L., García-Gonzalo, D., \& Pagán, R. (2018). Antimicrobial activity of suspensions and nanoemulsions of citral in combination with heat or pulsed electric fields. Letters in Applied Microbiology, 66, 63-70. https://doi.org/ 10.1111/lam.12815

Pandiselvam, R., Kaavya, R., Jayanath, Y., Veenuttranon, K., Lueprasitsakul, P., Divya, V., et al. (2020). Ozone as a novel emerging technology for the dissipation of pesticide residues in foods-a review. Trends in Food Science \& Technology, 97, 38-54. https://doi.org/10.1016/j.tifs.2019.12.017

Pandiselvam, R., Subhashini, S., Banuu Priya, E. P., Kothakota, A., Ramesh, S. V., \& Shahir, S. (2018). Ozone based food preservation: A promising green technology for enhanced food safety. Ozone: Science \& Engineering. https://doi.org/10.1080/ 01919512.2018.1490636

Pandiselvam, R., Sunoj, S., Manikantan, M. R., Kothakota, A., \& Hebbar, K. B. (2016). Application and Kinetics of ozone in food preservation. Ozone: Science \& Engineering. https://doi.org/10.1080/01919512.2016.1268947

Park, J.-B., Kang, J.-H., \& Song, K. B. (2018). Combined treatment of cinnamon bark oil emulsion washing and ultraviolet-C irradiation improves microbial safety of freshcut red chard. Lebensmittel-Wissenschaft und -Technologie- Food Science and Technology, 93, 109-115. https://doi.org/10.1016/j.lwt.2018.03.035

Pedrós-Garrido, S., Clemente, I., Calanche, J. B., Condón-Abanto, S., Beltrán, J. A., Lyng, J. G., \& Whyte, P. (2020). Antimicrobial activity of natural compounds against Listeria spp. and their effects on sensory attributes in salmon (Salmo salar) and cod (Gadus morhua). Food Control, 107, 106768. https://doi.org/10.1016/j. foodcont.2019.106768

Prakash, A., Baskaran, R., Paramasivam, N., \& Vadivel, V. (2018). Essential oil based nanoemulsions to improve the microbial quality of minimally processed fruits and vegetables: A review. Food Research International, 111, 509-523. https://doi.org/ 10.1016/j.foodres.2018.05.066

Priyadarshini, A., Rajauria, G., O’Donnell, C. P., \& Tiwari, B. K. (2019). Emerging food processing technologies and factors impacting their industrial adoption. Critical Reviews in Food Science and Nutrition, 59, 3082-3101. https://doi.org/10.1080/ 10408398.2018.1483890

Rendueles, E., Omer, M. K., Alvseike, O., Alonso-Calleja, C., Capita, R., \& Prieto, M. (2011). Microbiological food safety assessment of high hydrostatic pressure processing: A review. LWT-Food Science and Technology, 44(5), 1251-1260. https:// doi.org/10.1016/j.lwt.2010.11.001

Reyes-Jurado, F., Navarro-Cruz, A. R., Ochoa-Velasco, C. E., Palou, E., López-Malo, A., \& Ávila-Sosa, R. (2020). Essential oils in vapor phase as alternative antimicrobials: A review. Critical Reviews in Food Science and Nutrition, 60(10), 1641-1650. https:// doi.org/10.1080/10408398.2019.1586641

Sadowska, U., Matwijczuk, A., Niemczynowicz, A., Dróżdż, T., \& Żabiński, A. (2019). Spectroscopic examination and chemometric analysis of essential oils obtained from peppermint herb (Mentha piperita L.) and caraway fruit (Carum carvi L.) subjected to pulsed electric fields. Processes, 7(7), 466. https://doi.org/10.3390/pr7070466

Sagarzazu, N., Cebrián, G., Pagán, R., Condón, S., \& Mañas, P. (2013). Emergence of pulsed electric fields resistance in Salmonella enterica serovar Typhimurium SL1344. International Journal of Food Microbiology, 166, 219-225. https://doi.org/10.1016/j. ijfoodmicro.2013.07.001

Sánchez-Rubio, M., Taboada-Rodríguez, A., Cava-Roda, R., López-Gómez, A., \& MarínIniesta, F. (2016). Combined use of thermo-ultrasound and cinnamon leaf essential oil to inactivate Saccharomyces cerevisiae in natural orange and pomegranate juices. Lebensmittel-Wissenschaft und -Technologie-Food Science and Technology, 73, 140-146. https://doi.org/10.1016/j.1wt.2016.06.005
Sánchez-Rubio, M., Taboada-Rodríguez, A., Cava-Roda, R., López-Molina, D., \& MarínIniesta, F. (2018). Combined use of thermo-ultrasound and cinnamon leaf essential oil to inactivate Saccharomyces cerevisiae in culture broth and natural orange juice. Journal of Food Science \& Technology, 55, 4623-4633. https://doi.org/10.1007/ s13197-018-3401-x

Schlüter, O., \& Fröhling, A. (2014). Cold plasma for bioefficient food processing. In C. A. Batt, \& M.-L. Tortorello (Eds.), Encyclopedia of food microbiology (Vol. 2, pp. 948-953). London: Academic Pressv.

Shankar, S., Danneels, F., \& Lacroix, M. (2019). Coating with alginate containing a mixture of essential oils and citrus extract in combination with ozonation or gamma irradiation increased the shelf-life of Merluccius sp. fillets. Food Packaging and Shelflife, 22, Article 100434. https://doi.org/10.1016/j.fpsl.2019.100434

Shankar, S., Follet, P., Ayari, S., Hossain, F., Salmieri, S., \& Lacroix, M. (2020). Microbial radiosensitization using combined treatments of essential oils and irradiation-part B: Comparison between gama-ray and X-ray at different dose rates. Microbial Pathogenesis, 143, Article 104118. https://doi.org/10.1016/j.micpath.2020.104118

Silva-Espinoza, B. A., Palomares-Navarro, J. J., Tapia-Rodriguez, M. R., CruzValenzuela, M. R., González-Aguilar, G. A., Silva-Campa, E., et al. (2020) Combination of ultraviolet light-C and clove essential oil to inactivate Salmonella Typhimurium biofilms on stainless steel. Journal of Food Safety. , Article e12788. https://doi.org/10.1111/jfs.12788

Souza Pedrosa, G. T., Carvalho, R. J., Berdejo, D., Souza, E. L., Pagán, R., \& Magnani, M. (2019). Control of autochthonous spoilage lactic acid bacteria in apple and orange juices by sensorially accepted doses of Citrus spp. essential oils combined with mild heat treatments. Journal of Food Science, 84, 848-858. https://doi.org/10.1016/j. ijfoodmicro.2020.108837

Taştan, Ö., Pataro, G., Donsì, F., Ferrari, G., \& Baysal, T. (2017). Decontamination of fresh-cut cucumber slices by a combination of a modified chitosan coating containing carvacrol nanoemulsions and pulsed light. International Journal of Food Microbiology, 260, 75-80. https://doi.org/10.1016/j.ijfoodmicro.2017.08.011

Tawema, P., Han, J., Vu, K. D., Salmieri, S., \& Lacroix, M. (2016). Antimicrobial effects of combined UV-C or gamma radiation with natural antimicrobial formulations against Listeria monocytogenes, Escherichia coli O157: H7, and total yeasts/molds in fresh cut cauliflower. Lebensmittel-Wissenschaft und -Technologie- Food Science and Technology, 65, 451-456. https://doi.org/10.1016/j.lwt.2015.08.016

Turek, C., \& Stintzing, F. C. (2013). Stability of essential oils: A review. Comprehensive Reviews in Food Science and Food Safety, 12(1), 40-53. https://doi.org/10.1111/ 1541-4337.12006

Vurmaz, A. K., \& Gündüz, G. T. (2020). Inhibition of mold growth on the surface of dried persimmons using combined treatments of UV-C light and clove oil. Innovative Food Science \& Emerging Technologies, 61, 102336. https://doi.org/10.1016/j. ifset.2020.102336

Wang, M. S., Wang, L. H., Bekhit, A. E. D. A., Yang, J., Hou, Z. P., Wang, Y. Z., \& Zeng, X. A. (2018). A review of sublethal effects of pulsed electric field on cells in food processing. Journal of Food Engineering, 223, 32-41. https://doi.org/10.1016/j. jfoodeng.2017.11.035

Yoo, J. H., Baek, K. H., Heo, Y. S., Yong, H. I., \& Jo, C. (2021). Synergistic bactericidal effect of clove oil and encapsulated atmospheric pressure plasma against Escherichia coli 0157:H7 and Staphylococcus aureus and its mechanism of action. Food Microbiology, 93, Article 103611. https://doi.org/10.1016/j.fm.2020.103611

Zallaghi, N., \& Ahmadi, M. (2020). Combined action of Lavandula angustifolia Miller essential oil and gamma irradiation treatment on some biological aspects of the Mediterranean flour moth Ephestia kuehniella (Zeller). International Journal of Pest Management. https://doi.org/10.1080/09670874.2020.1723819

Zhang, H., Tsai, S., \& Tikekar, R. V. (2021). Inactivation of Listeria innocua on blueberries by novel ultrasound washing processes and their impact on quality during storage. Food Control, 121, Article 107580. https://doi.org/10.1016/j.foodcont.2020.107580

Zhang, H., Wang, S., Goon, K., Gilbert, A., Huu, C. N., Walsh, M., et al. (2020). Inactivation of foodborne pathogens based on synergistic effects of ultrasound and natural compounds during fresh produce washing. Ultrasonics Sonochemistry, 64, Article 104983. https://doi.org/10.1016/j.ultsonch.2020.104983 